University of Louisville

ThinkIR: The University of Louisville's Institutional Repository

Electronic Theses and Dissertations

$5-2006$

\title{
Analysis of landfills C-746-S and C-746-T at the Paducah Gaseous Diffusion Plant.
}

Paul Jacob Cooper 1981-

University of Louisville

Follow this and additional works at: https://ir.library.louisville.edu/etd

\section{Recommended Citation}

Cooper, Paul Jacob 1981-, "Analysis of landfills C-746-S and C-746-T at the Paducah Gaseous Diffusion Plant." (2006). Electronic Theses and Dissertations. Paper 275.

https://doi.org/10.18297/etd/275

This Master's Thesis is brought to you for free and open access by ThinkIR: The University of Louisville's Institutional Repository. It has been accepted for inclusion in Electronic Theses and Dissertations by an authorized administrator of ThinkIR: The University of Louisville's Institutional Repository. This title appears here courtesy of the author, who has retained all other copyrights. For more information, please contact thinkir@louisville.edu. 


\title{
ANALYSIS OF LANDFILLS C-746-S AND C-746-T AT THE PADUCAH GASEOUS DIFFUSION PLANT
}

\author{
By \\ Paul Jacob Cooper \\ B.S., University of Louisville, 2005
}

\author{
A Thesis \\ Submitted to the Faculty of the \\ University of Louisville \\ Speed School of Engineering \\ As Partial Fulfillment of the Requirements \\ For the Professional Degree
}

MASTER OF ENGINEERING

Department of Civil and Environmental Engineering

May 2006 
ANALYSIS OF LANDFILLS C-746-S AND C-746-T AT THE

PADUCAH GASEOUS DIFFUSION PLANT

Submitted by:

Paul Jacob Cooper

A Thesis Approved on

By the Following Reading and Examination Committee:

D.J. Hagerty, Thesis Director

James C. Watters

J.P. Mohsen 
ABSTRACT

Contamination can be very difficult to remove from water. Once this water seeps into the ground, the difficulty grows exponentially. The Paducah Gaseous Diffusion Plant, located in Paducah, Kentucky, has contaminated the groundwater. The contaminants that pose an environmental threat are Trichloroethylene and Technetium-99. Trichloroethylene is used as a degreasing solvent, while Technetium- 99 is a by-product of enriching uranium.

This study involves investigating potential sources of Trichloroethylene and Technetium-99. The potential sources are two landfills, the C-746-S landfill and the C-746$\mathrm{T}$ landfill. Data from monitoring wells located around the two landfills were analyzed to determine if the two landfills are sources of contamination. Data from leachate reports were compared to monitoring well data to investigate the possibility of leakage from the landfill containing Trichloroethylene or Technetium-99. 
TABLE OF CONTENTS

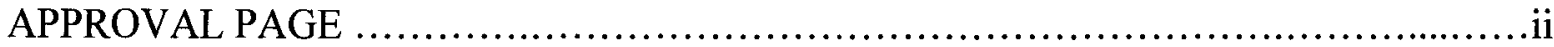

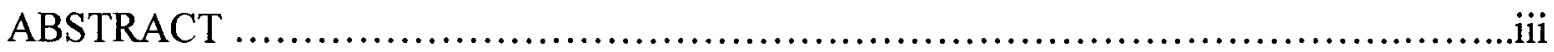

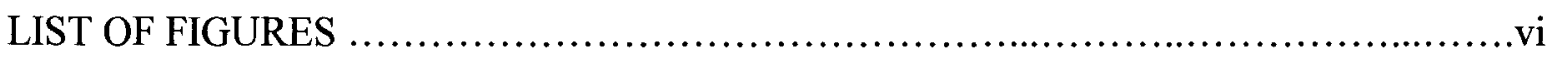

I. INTRODUCTION ............................................................. 1

II. SITE INFORMATION .................................................... 9

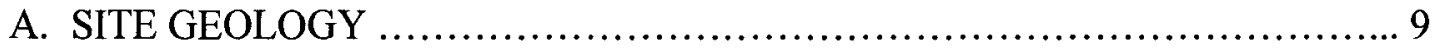

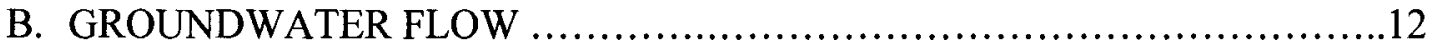

C. LANDFILL DATA ........................................................... 18

D. PRINCIPAL CONTAMINANTS ........................................ 20

E. OTHER POTENTIAL CONTAMINANTS: LANDILL LEACHATE CHEMICALS AND TOXINS ................................................ 23

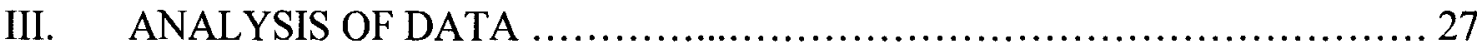

A. PARAMETERS ANALYSIS VERSUS TIME ............................... 28

B. PARAMETERS ANALYSIS VERSUS TIME AND SPACE ................. 36

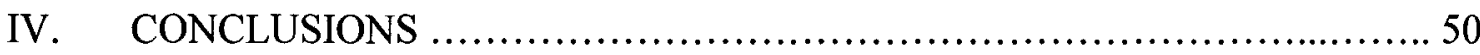

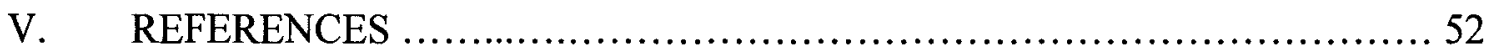


APPENDIX A - TYPICAL CHEMICAL ANALYSIS OF

GROUNDWATER SAMPLES

APPENDIX B - LEACHATE ANALYSIS ..................................... 57

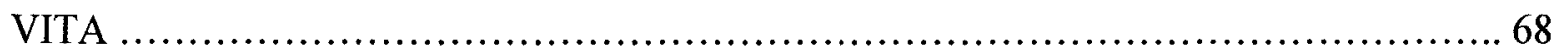




\section{LIST OF FIGURES}

Figure 1A. Location of PGDP .......................................................... 2

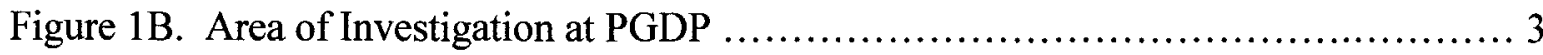

Figure 2. Geologic Cross-section Beneath PGDP ...................................... 5

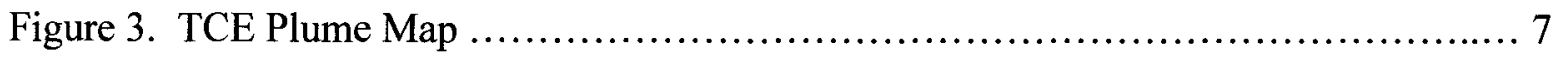

Figure 4. TC-99 Plume Map ........................................................ 8

Figure 5. Hydrogeologic Units at PGDP .............................................. 14

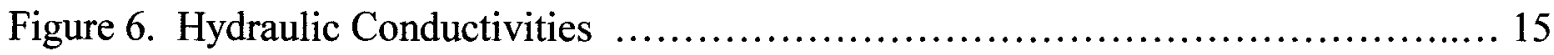

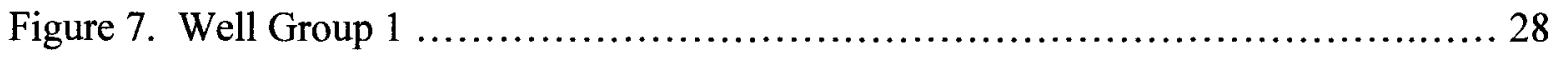

Figure 8. TCE Well Group 1 Plot of Concentration versus Time ....................... 29

Figure 9. TC-99 Well Group 1 Plot of Activity versus Time ........................... 30

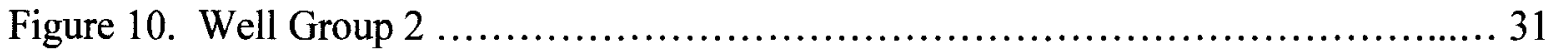

Figure 11. TCE Well Group 2 Plot of Concentration versus Time ....................... 32

Figure 12. TC-99 Well Group 2 Plot of Activity versus Time ............................ 33

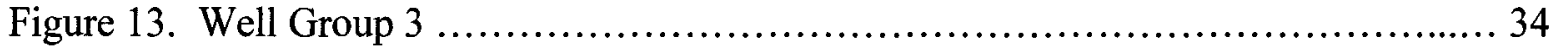

Figure 14. TCE Well Group 3 Plot Concentration versus Time .......................... 35

Figure 15. TC-99 Well Group 3 Plot Activity versus Time ............................ 36

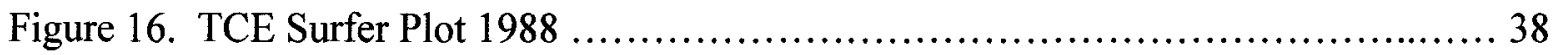

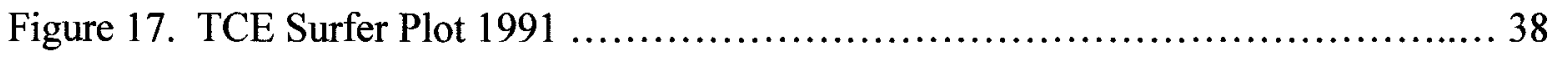

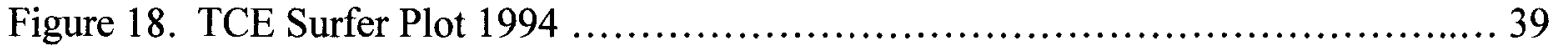

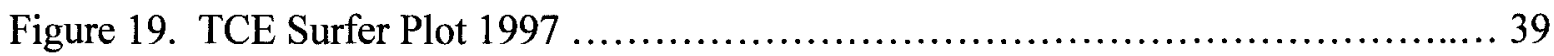




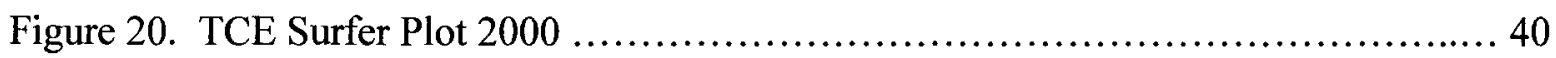

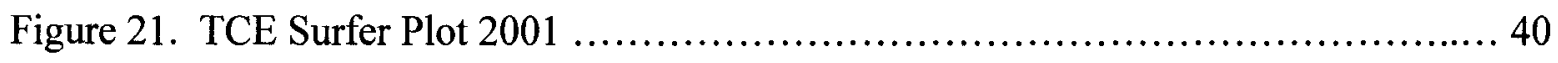

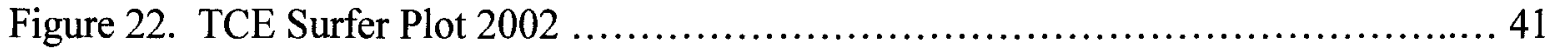

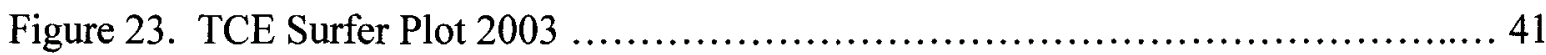

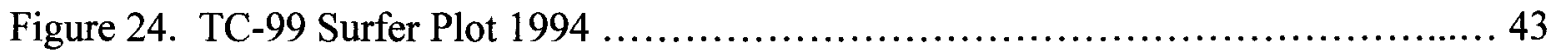

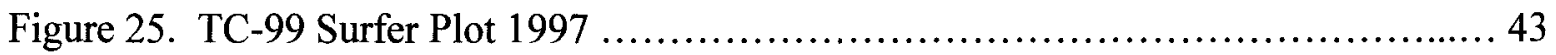

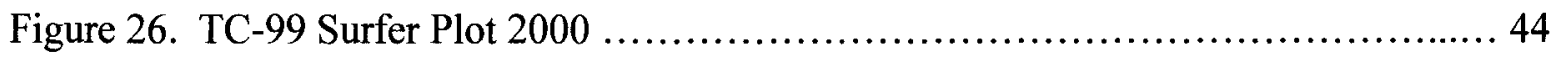

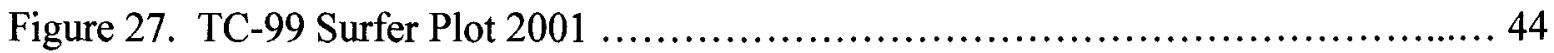

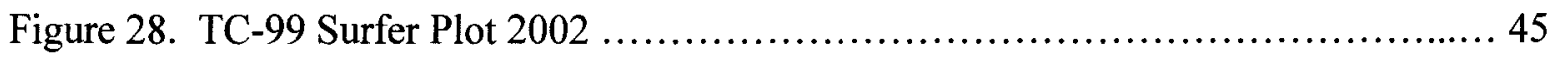

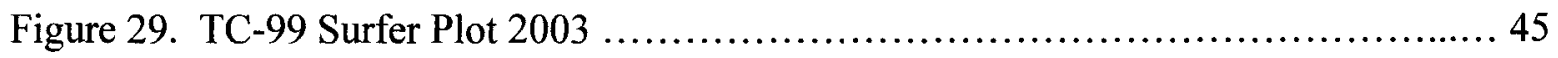

Figure 30. MW 179 and MW 275 Location ......................................... 47

Figure 31. TC-99 Activity Plot of MW 179 and MW $275 \ldots \ldots \ldots \ldots \ldots \ldots \ldots \ldots \ldots . \ldots . \ldots \ldots$ 


\section{INTRODUCTION AND OVERVIEW OF THE PADUCAH GASEOUS DIFFUSION PLANT}

Located 10 miles west of Paducah, Kentucky, the Paducah Gaseous Diffusion Plant (PGDP) began operations in 1954. Figure 1A maps the location of the PGDP, while Figure 1B provides a closer image of the plant location. The plant initially produced enriched uranium that was enriched further at the Portsmouth Gaseous Diffusion Plant in Ohio. The Paducah Plant soon expanded to include nuclear weapons disassembly and disposal, uranium milling and disposal, and exotic metals recovery. The plant in 2006 produced uranium for commercial reactors, and used the uranium by-products for armor plating and anti-tank penetrators. The 2006 missions for the PGDP included: fuel production for commercial power reactors; environmental restoration of the site; and storage of depleted uranium hexafluroide.

The site is located on a large 3,422-acre complex, with 750 acres enclosed with fences. There are approximately 100 small lakes and ponds, with 7 settling basins and 17 gravel pits. Two major channels carry water: Bayou Creek is located on the west side of the site, with Little Bayou Creek located on the east side. 


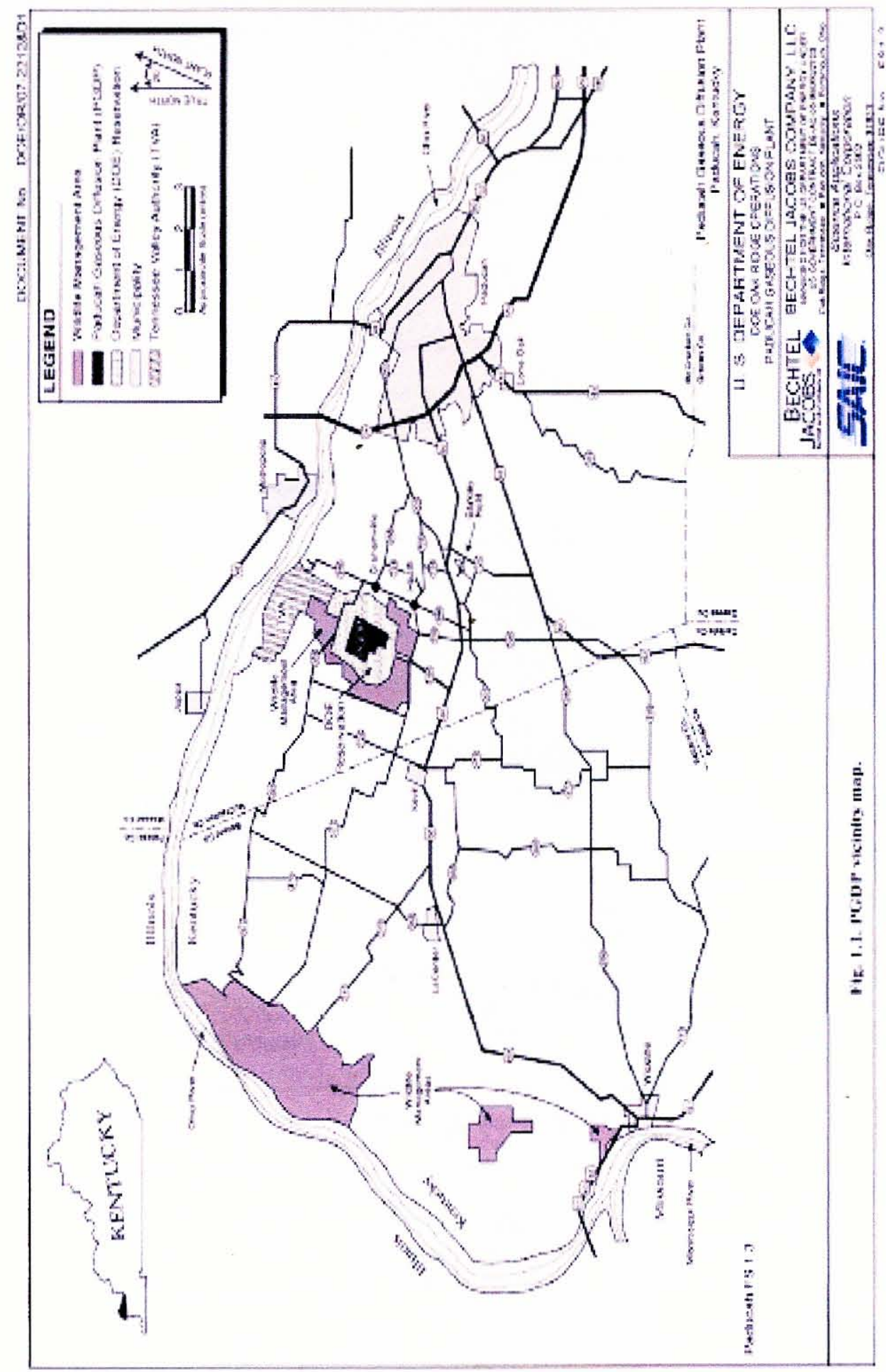

Figure 1A - Location of PGDP (DOE 1997b) 


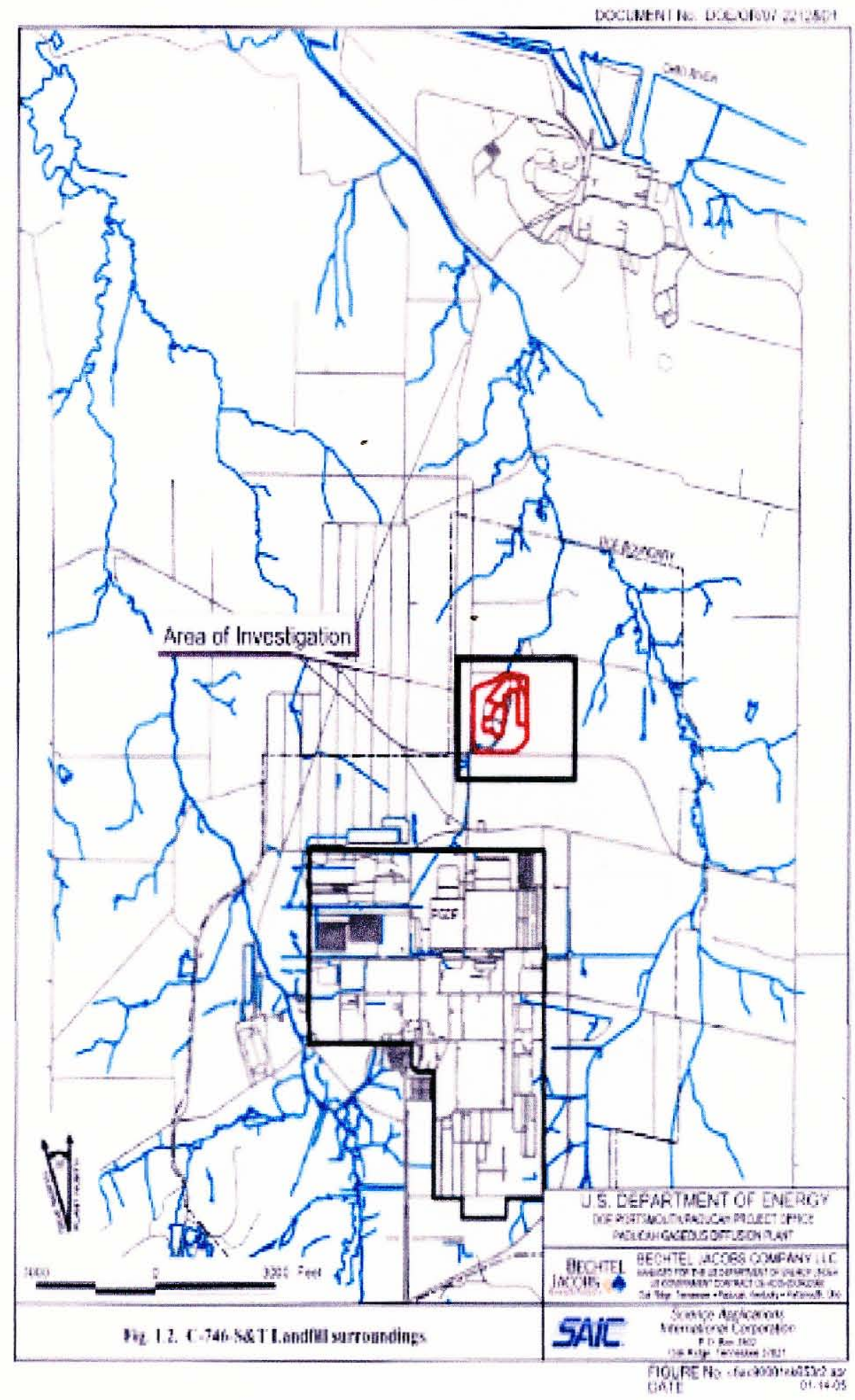

Figure 1B - Area of Investigation at PGDP (DOE 1997b)

Figure 2 shows a geologic cross-section beneath the PGDP. Underneath the PGDP are three major geologic layers. The Upper Continental Recharge System (UCRS) consists 
of clayey silts with interbedded sands and gravels. The UCRS is approximately 60 feet thick. Beneath the UCRS is the $30-40$ feet thick Regional Gravel Aquifer System (RGA). The RGA contains discontinuous sands along with lower continental deposits. Located underneath the RGA is the semi-permeable McNairy formation. The groundwater flow has been determined to be approximately $3 \mathrm{ft} /$ day, with a general flow direction of northnortheast. 


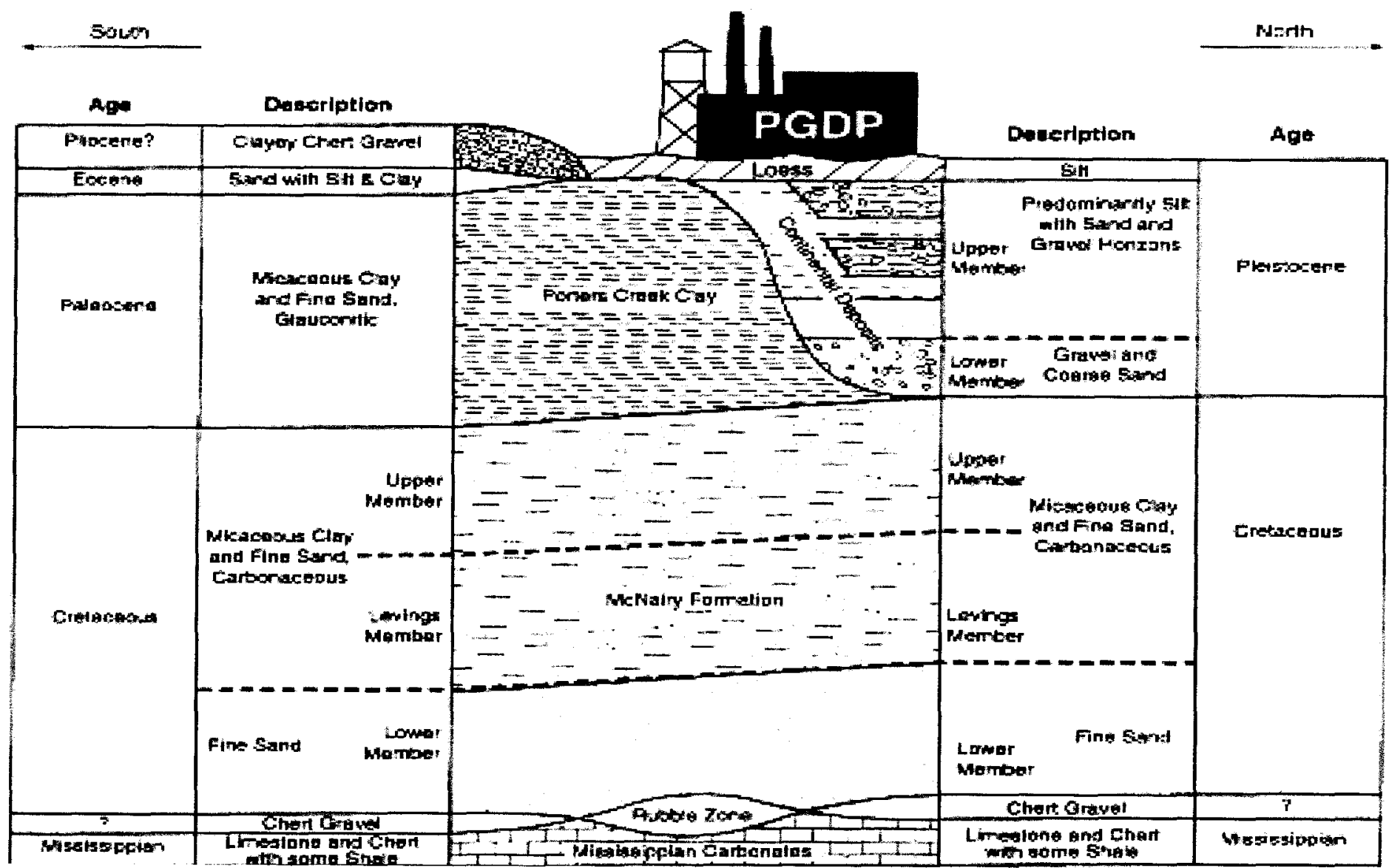


The PGDP site has been identified as the source of groundwater contamination. The groundwater has been contaminated with TCE and TC-99. The plume maps for TCE and TC-99 are shown in Figures 3 and 4, respectively.

The problem addresses the C-746-S and C-746-T landfills. The landfills are located north of the plant, as shown in the area of investigation in Figure 1B. By transposing Figure 3 and Figure 4 on top of Figure 1B, the landfill site was located within the TCE and TC-99 plume. The question becomes, "Are the landfills the source of the TCE and TC-99 contamination?" The following sections address this issue. This document presents the general site characteristics. These include geology, groundwater flow, landfill contents, and information on the principal contaminants. The thesis then provides a description on the analysis of the data of groundwater contaminant and their levels. Finally the thesis includes three conclusions to answer the question. 


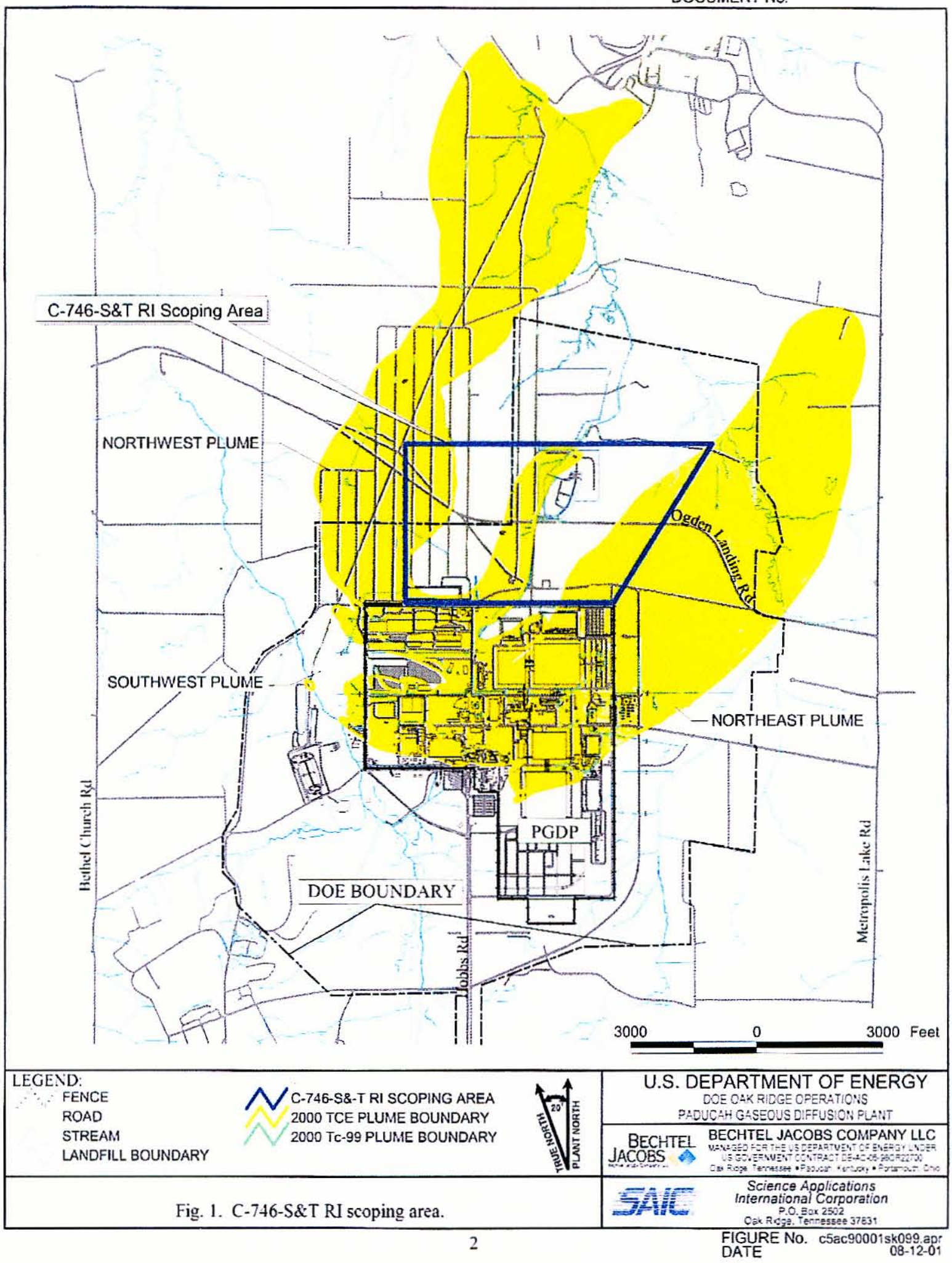

Figure 3 - TCE Plume Map (Bechtel Jacobs Company LLC) 


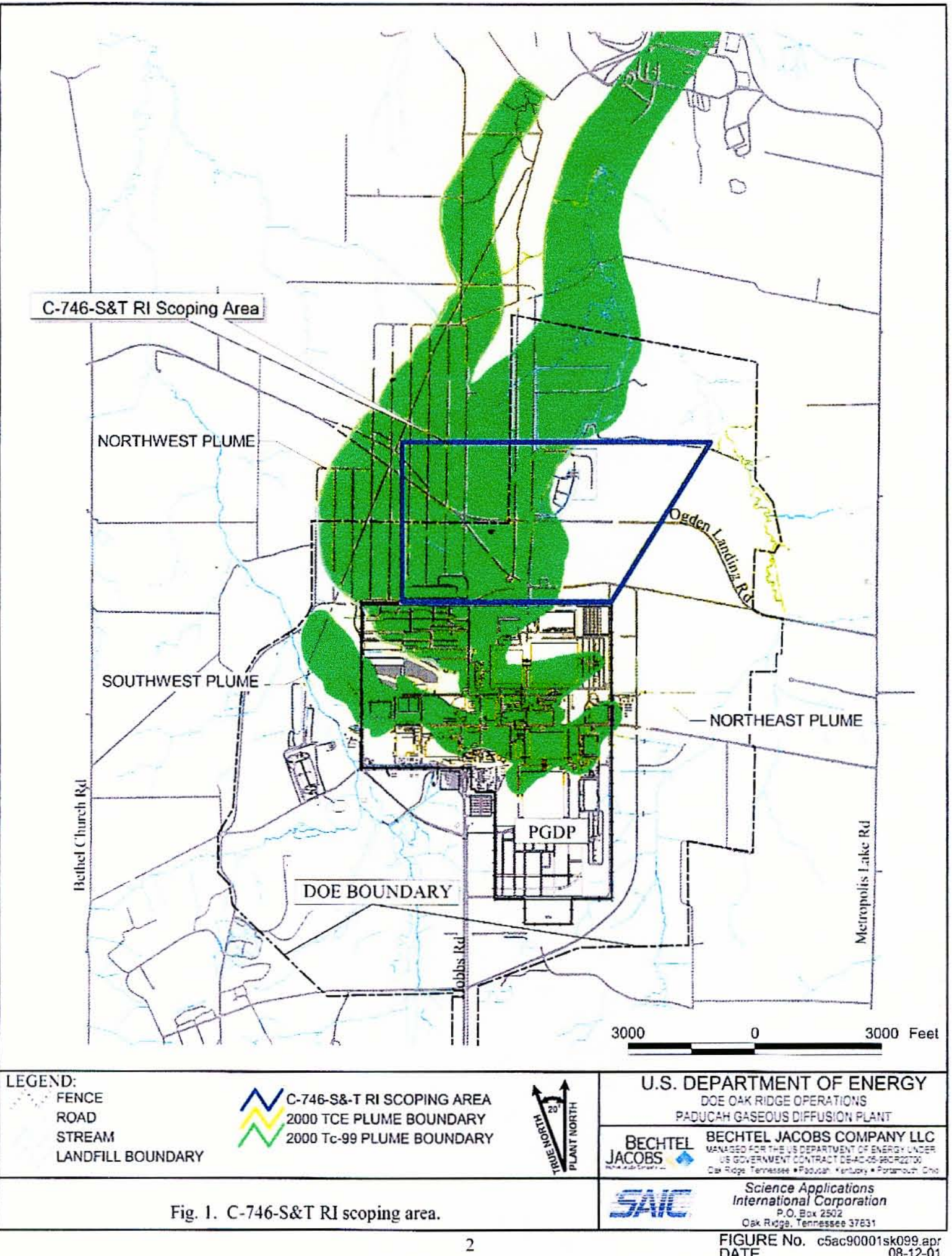

Figure 4 - TC-99 Plume Map (Bechtel Jacobs Company LLC) 


\section{SITE INFORMATION}

This section addresses site characteristics. The geology and groundwater flow conditions are summarized. The geology of the site was used to develop the groundwater flow model, identify important chemical properties of the soil, and predict potential contamination problems. The groundwater flow model was used to determine the dispersion of the principal contaminants, along with leachate chemicals and toxins. The landfill contents also are addressed in this section. The landfill contents allowed insight into the possibility of the principal contaminants being present. The principal contaminants and leachate chemicals and toxins at the PGDP site also follow.

\section{A. Site Geology}

The geologic makeup of a site provides important data to an investigation. The geology provides information used to develop groundwater models, identify important chemical properties of the soil, and predict potential contamination problems. Critical features include geologic structures such as faults, and geologic units, particularly units defined on the basis of groundwater hydrology.

Outcrop maps of Southern Illinois show traces of faults and related structures. The same faults and related structures are expected in the PGDP area. The Illinois Geological Survey has identified faults and grabens within the PGDP area (DOE 1997b). The Kentucky Geologic Survey also has identified possible problems with two lineaments or fracture zones mapped through the PGDP area (DOE 1997b). The stratigraphic relationships also point to faulting that has continued into the Pleistocene age. The consistent elevation of the 
depositional horizons indicates that faulting is absent in the continental deposits. The boreholes drilled at the site have returned no evidence of faulting in the surficial deposits.

The upper bedrock beneath the PGDP consists of Mississippian limestone and chert. A north regional dip towards the Illinois Basin exists. The units of the Mississippi Embayment and the Gulf Coastal Plain Province form a regional unconformity at the top of the bedrock. The Mississippi Embayment sediments belong to the Cretaceous McNairy Formation, the Paleocene Porters Creek Clay, and undifferentiated Eocene sands of the Wilcox Formation and Claiborne Group. The site is located on the northern tip of the Mississippi Embayment. Sands and gravels of the alluvial fan, located in parts of southern Illinois, were eroded and replaced by sediments of the Tennessee River basin. During the Pleistocene, the top of the McNairy Formation was disturbed by the Tennessee River. The ancestral river carved a basin in the shallow sediments. The Ohio River tends to follow the course taken by the ancestral river, but is displaced to the north of a loop in the ancestral river. The ancestral Tennessee River valley is filled with Pleistocene river and lake deposits, as shown in Figure 2, presented in Chapter I.

The following is an explanation of the different stratigraphic sections, shown in Figure 2, in chronological order, from oldest to youngest.

Mississippian Limestone - The Mississippian limestone forms the bedrock beneath the site. The limestone contains chert nodules with a gray tint. The limestone has been suggested to be cavernous from the information contained in the drillers' logs. Rubble Zone - The rubble zone consists of chert and limestone gravels. The zone also contains limestone boulders embedded in sands or clays. The thickness of the rubble zone varies from 10 to 45 feet. 
McNairy Formation - The thickness of the Cretaceous McNairy Formation ranges from 221 to $247 \mathrm{ft}$. The formation can be classified into three different layers, the lower, middle and upper. The upper layer ranges from 60 to $69 \mathrm{ft}$ in thickness. The layer consists mainly of interbedded silts and fine sands. The middle layer contains thick silt and clay beds, ranging from 56 to $62 \mathrm{ft}$ in thickness. The lower layer ranges from 100 to $120 \mathrm{ft}$ in thickness and contains silt and clay beds with well-sorted fine sands between the silt and clay strata. Because of chemical weathering and physical erosion, the top layer of the McNairy Formation has less silt and clay content.

Porters Creek Clay - The thickness of this clay layer is approximately $100 \mathrm{ft}$. This massive glauconitic clay contains interbeds of sand. The clay represents a layer of ancestral Tennessee River sediments.

Eocene Sands - The thickness of this sand layer is approximately $100 \mathrm{ft}$. The sand overlays the Porters Creek Clay south of the PGDP.

Pliocene Gravels - The thickness of this layer can range from zero to $30 \mathrm{ft}$. The gravel consists of angular and sub-angular pieces. The gravel contains poorly sorted silty sands south of the plant. The age of the gravel ranges from Miocene to Pleistocene. The southeast quadrant of the plant overlies this gravel.

Lower Continental Deposits - The deposits have an average thickness of $30 \mathrm{ft}$, with a bottom of approximately $60 \mathrm{ft}$. The deposits consist of medium to coarse sand and chert gravel.

Upper Continental Deposits - Three depositional layers have been classified out of the total deposit. A basal sand defines the lower unit. The sand becomes siltier as it approaches the middle unit. The middle unit consists of fine-textured sediments. The 
thickness of the middle unit ranges from 10 to $40 \mathrm{ft}$. The upper unit contains sand and gravel. The sand and gravel varies greatly in texture and sorting. Frequent vertical fracture traces are present within the deposit. The fractures are filled with silt or clay.

Loess - The loess is typically 10 to $15 \mathrm{ft}$ thick beneath the PGDP. The silt facies from the upper continental deposits make the loess deposits difficult to differentiate. The loess has been replaced with fill material for construction of building supports in many places.

\section{B. Groundwater Flow}

Once a contaminant enters the ground, groundwater flow can disperse the contaminant. In order to determine the dispersion, a groundwater flow model must be developed. The model must define accurately the soil layers present, the hydraulic properties of the soil layers, and the possible connectivity of the layers. Once the model has been completed, then the contaminant can be tracked and possible solutions for the containment and cleanup of the contaminant can be proposed.

In order to develop an accurate conceptual model for the PGDP site, lithologic and geologic units were grouped together according to flow characteristics. The grouping of strata is called a hydrogeologic unit. The PGDP area can be represented by six defined hydrogeologic units. These units are defined as:

HU 1 - Loess

HU 2 - Permeable lenses (UCRS or Terrace Deposits)

HU 3 - UCRS lower confining unit 
HU 4 - Regional Groundwater Aquifer (upper zone)

HU 5 - Regional Groundwater Aquifer (lower zone)

HU 6 - McNairy Formation Flow System.

Figure 5 gives a graphical representation of the hydrogeologic units. Figure 6 presents low, high and mean values for hydraulic conductivity of the units, where available. The loess is not an aquifer at the PGDP site. 


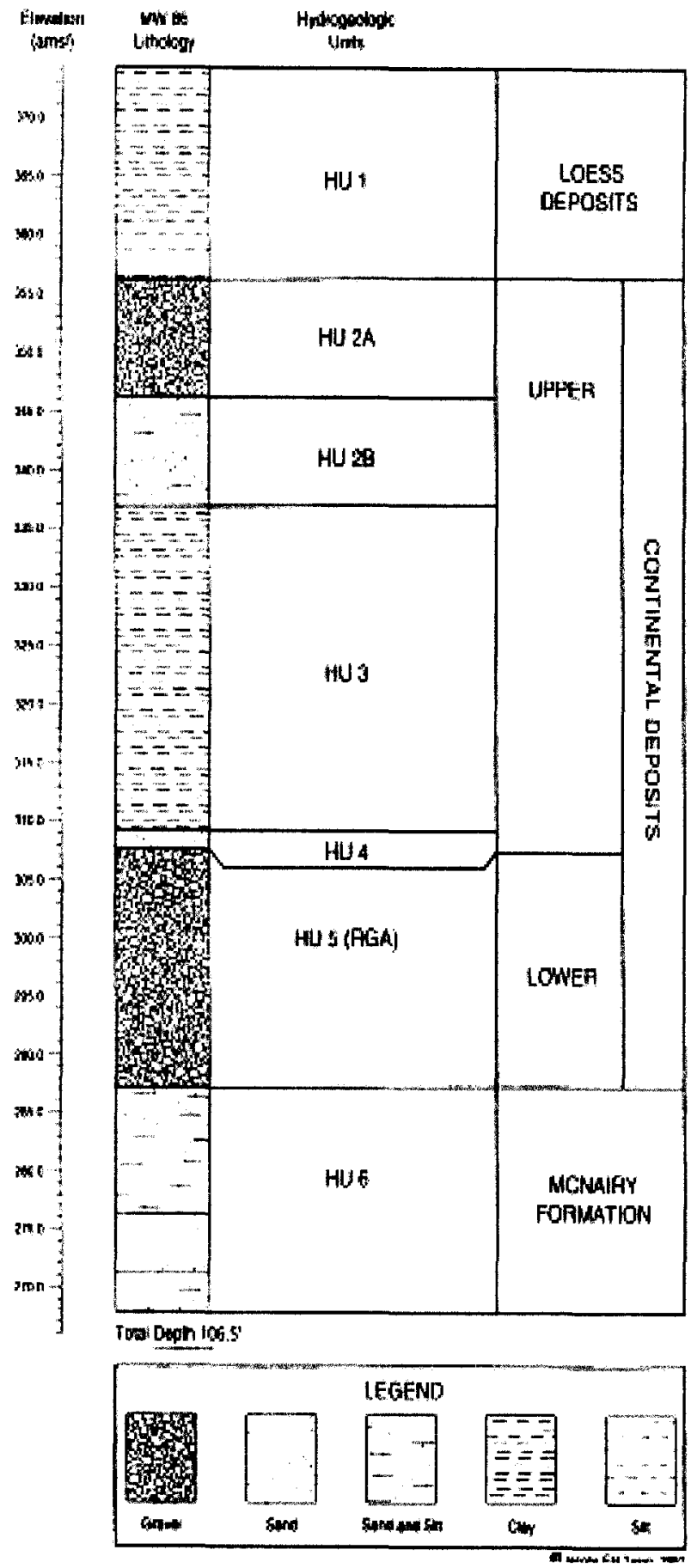

Figure 5 - Hydrogeologic Units at PGDP (DOE 1997b) 
Table 3-1. Ilydraulic Conductlvily Data

\begin{tabular}{|c|c|c|c|c|}
\hline $\begin{array}{c}\text { Hydnigedogir } \\
\text { Unit }\end{array}$ & 1now & Meant & High & Tyje of That und Reference \\
\hline \multicolumn{5}{|l|}{ LCRS - K } \\
\hline $\begin{array}{l}\{\mathrm{cm} / \mathrm{sec}\} \\
(1 / 1 / \mathrm{day})\end{array}$ & $\begin{array}{l}1.04 \times 10^{3} \\
290 \times 10^{3}\end{array}$ & & $\begin{array}{c}6.93 \times 10^{4} \\
3.4\end{array}$ & $\begin{array}{l}\text { Slug tosts } \\
\text { [CH2M HILL, }(99) \mid\end{array}$ \\
\hline \multicolumn{5}{|l|}{ HU $5-K$} \\
\hline $\begin{array}{l}\text { fim/ar) } \\
(f \mathrm{f} / \mathrm{day})\end{array}$ & & $\begin{array}{c}20 \times 10^{\circ} \\
10.57\end{array}$ & & $\begin{array}{l}\text { P'umping lest at } C-104 \\
\text { (Terran, 1999) }\end{array}$ \\
\hline $\begin{array}{l}\mid[m, / 4 m \mid \\
(\mathrm{ft} / \mathrm{day})\end{array}$ & $\begin{array}{l}10 \times 10^{\circ} \\
300 \times 10^{\circ}\end{array}$ & & $\begin{array}{l}5.19 \times 10^{7} \\
3 .(1) \times 10^{1}\end{array}$ & $\begin{array}{l}\text { Tulinjing hes } \\
\text { at C-J33 Teran, 1421) }\end{array}$ \\
\hline \multicolumn{5}{|l|}{$\operatorname{RGA}\left(K_{0}\right)$} \\
\hline 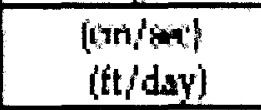 & $\begin{array}{c}336 \times 10^{5} \\
0.09\end{array}$ & & $\begin{array}{c}5.16 \times 11^{2} \\
146\end{array}$ & 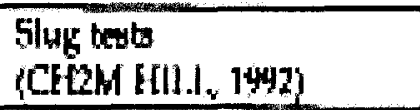 \\
\hline $\begin{array}{l}|c m i / s| \\
\text { (it/dsy) }\end{array}$ & $\begin{array}{c}187 \times 10^{7} \\
53\end{array}$ & & $\begin{array}{c}377 \times 10^{3} \\
107\end{array}$ & $\begin{array}{l}\text { Pusuping leet } \\
\text { at C404 (Terran, 14:0) }\end{array}$ \\
\hline $\begin{array}{l}\text { (unisur) } \\
\text { (it/day) }\end{array}$ & $\begin{array}{c}353 \times 10^{2} \\
1(x)\end{array}$ & & $\begin{array}{c}524 \times 11^{7} \\
150\end{array}$ & $\begin{array}{l}\text { Tumping lest } \\
\text { 11 C-597 } \\
\text { (C)HבM HILL. 1992) }\end{array}$ \\
\hline $\begin{array}{l}\text { !im/asl } \\
\text { itt/day| }\end{array}$ & $\begin{array}{c}3.53 \times 10 \\
1,0 \mathrm{man}\end{array}$ & & $\begin{array}{c}4.23 \times 10^{4} \\
1,200\end{array}$ & $\begin{array}{l}\text { Pumping test } \\
\text { al } 6.313 \text { Termin. } \mid 92\end{array}$ \\
\hline $\begin{array}{l}(m / s x) \\
(\mid t) /(n y)\end{array}$ & $\begin{array}{l}8.45 \\
2,665 \\
\end{array}$ & & $\begin{array}{l}2.01 \\
5,7 \times 1 \\
\end{array}$ & 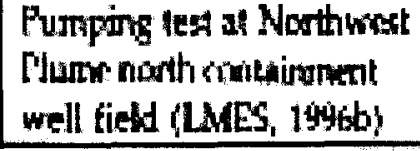 \\
\hline \multicolumn{5}{|l|}{ MeNairy $\left(K_{n}\right)$} \\
\hline $\begin{array}{l}(\mathrm{m} / \mathrm{sa}\rangle) \\
|\mathrm{tt} / \mathrm{day}\rangle\end{array}$ & $\begin{array}{c}2.14+\times 10^{8} \\
0.08 \\
\end{array}$ & & $\begin{array}{c}180 \times 10^{4} \\
0.52\end{array}$ & 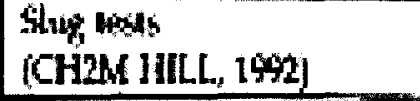 \\
\hline
\end{tabular}

K. Mondurnal tratrinds sondustmily

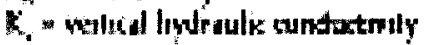

Figure 6 - Hydraulic Conductivities (DOE 1997b)

\section{Upper Continental Recharge System}

The upper continental recharge system (UCRS) defines the uppermost water-bearing layer. The layer contains lenses of sand and gravel material. The layer contains two hydrogeologic subunits, $\mathrm{HU} 2 \mathrm{~A}$ and $\mathrm{HU} 2 \mathrm{~B}$. HU 2A is the uppermost unit, while $\mathrm{HU} 2 \mathrm{~B}$ 
defines the lower unit. A continuous clay layer separates the two subunits. Each layer also shows different head values, corresponding to different water elevations. Each unit does show a strong downward vertical gradient. The hydraulic conductivity of the two layers can be variable. Slug tests reveal an average hydraulic conductivity for HU $2 \mathrm{~A}$ of $4.24 \times 10^{-5}$ $\mathrm{cm} / \mathrm{sec}$ and $7.41 \times 10^{-4} \mathrm{~cm} / \mathrm{sec}$ for HU 2B (DOE 1997b). According to McConnell (1992), the vertical hydraulic conductivity can be approximated by $1 / 10^{\text {th }}$ the horizontal conductivity. The dominant flow in the layers is downward.

The site lacks the historical data to determine accurately the hydraulic conductivity field. The hydraulic conductivity field can be better understood by performing a geostatistical evaluation. DOE (1997a) used experimental semivariograms to evaluate the hydraulic conductivity field. The analysis was performed on layers HU $2 \mathrm{~A}$ and $\mathrm{HU} 2 \mathrm{~B}$. The geostatistical analysis determined the spatial correlation structure of hydraulic conductivity. The semivariogram analysis determined the spatial distribution of lithologic classes. Semivariogram analysis was conducted for indicator-transformed data. Lithologic Class 3 and Class 4 were defined by semivariograms used to evaluate the spatial correlation structure. Class 2 was unable to be designated due to limited data. To evaluate the site thoroughly, multiple direction semivariogram analysis was performed. At large distances, hydraulic conductivity, lithology, and facies were spatially correlated. Four key conclusions came from the semivariogram analysis. First, the HU 2A and HU 2B are spatially connected as shown by correlated structures. The semivariograms show omnidirectional and directional correlation. The lithologic classes are also spatially correlated. The second key conclusion states the best model for Lithologic Class 3 in HU 2A is a pure nugget model. That model shows the clayey and silty sand in HU $2 \mathrm{~A}$ is not spatially correlated; i.e., the fine soils are 
present in lenses, not continuous layers. Thirdly, the north-south and northeast-southwest directions show the best spatial correlation. The last key conclusion involves the accuracy of the data. The correlation in HU 2A ranges from 45.7 to 228.6 meters. A majority of the data correlated with $\mathrm{HU} 2 \mathrm{~A}$ is less than 91.4 meters. The correlation in HU 2A can be assumed to be less than 91.4 meters.

The UCRS shows steep vertical hydraulic gradients. These vertical hydraulic gradients range from 0.5 to 1 meter/meter. The large gradients make the analysis of the water table difficult. The water table has a broad trough located in the northeast and central areas. There is also a ditch in the northwest quadrant, representing a linear discharge area. The west side of the PGDP has a hydraulic gradient toward Bayou Creek in the UCRS.

To summarize, the UCRS contains many discontinuous zones of clay and silt embedded in sandy layers, as well as some continuous fine-grained strata. Gradients indicate overall downward flow, but local flow could be horizontal on the upper surfaces of clay or silt lenses.

\section{$\underline{\text { Regional Gravel Aquifer }}$}

The HU 4 and HU 5 hydrogeologic units define the Regional Gravel Aquifer (RGA). The two units generally work together. The lower continental deposits define HU 5 , while discontinuous sand makes up HU 4. The two units showed no water elevation change in nested wells, revealing that the two units are hydraulically connected.

As stated before, the RGA ranges in thickness from 3 to 17 meters. Figure 6 shows the results from conductivity tests performed in the RGA. These tests include aquifer tests by Terran (1990), CH2M Hill (1992), and LMES (1996). Each test returned different values for hydraulic conductivity, ranging from $0.09 \mathrm{ft} /$ day to $5700 \mathrm{ft} /$ day. 
HU 3 provides a confining layer for the RGA. HU 3, the lower unit of the UCRS, consists of silt and clay facies. These facies restrict the vertical flow of groundwater. The layer is continuous over the site. The Ohio River influences the groundwater flow in the RGA. When the stage of the Ohio River is low, the groundwater in the RGA flows north to northeast. During high stages of the Ohio River, it is possible for the groundwater flow to slow or even reverse direction.

\section{$\underline{\text { McNairy Formation }}$}

The hydraulic gradient in this formation is toward the Ohio River. The slope of the gradient is almost parallel to that in the RGA. The Porters Creek Clay layer caps the formation, making recharging of the formation minimal. However, the clay layer is absent around the PGDP, so the RGA and McNairy Formation hydraulically are connected. Monitoring wells have measured the vertical gradient to be 0.03 meter/meter. The McNairy Formation does have a high hydraulic potential near the Ohio River from a steeper potentiometric surface of the RGA. The hinge line, along which the vertical hydraulic gradient does not exist, runs parallel to the Ohio River at the northern boundary of the site. The Upper and Levings Members of the McNairy formation show very low conductivities. It would take approximately 12,000 years for water to flow vertically through the 125 -ft thick layer.

\section{Landfill Data}

The C-746-S and C-746-T landfills are located on an older solid waste management unit, SWMU 145, which is located just beneath the S\&T landfills. The SWMU is approximately 44 acres in size. The units were constructed in the early 1950's. A report 
from Union Carbide in 1973 contains indications of what is in the units (Union Carbide 1973). The report states that the site contractor at that time would discard all types of scrap and waste materials into the landfills. The collection of construction waste continued until the late 1980 's. Once a year, the scrap would be moved into piles or depressions, and covered with soil. Previous site investigations discovered materials such as roofing, construction debris, and flyash in the landfills (DOE 2001). No reports state that TCE or TC99 was placed in the landfill.

A report found within files of the Division of Waste of the Department of Environmental Protection in Frankfort provides some insight into the $\mathrm{S}$ landfill contents. The 1980 report provides information on operators, refuse path, landfill operation, and landfill contents. The landfill was operated and maintained by the Plant Services Department. Special pans were located throughout the plant, labeled "Sanitary Landfill Only". Input to the pans was limited to paper, rags, wood, floor sweepings, garbage, paint and soft drink cans. The refuse was taken to the landfill, where it was placed with fly and bottom ash from the C-600 Steam Plant. The refuse was placed in a trench of ash, then backfilling over the refuse was done with ash. Dirt and clay was placed over the ash to facilitate runoff and prevent erosion and leaching. Daily disposals were about 2.7 tons of refuse and 15.9 tons of ash. Cover material was applied only weekly.

Ash provides most of the input to the landfill. Approximately 5,800 tons per year of ash were added to the sanitary landfill. Paper provided the second highest flow, at 650 tons each year. Wood, metal, garbage, and miscellaneous refuse provided about 100 tons each per year. Hazardous waste was taken to the sanitary landfill as well. Approximately five tons per year of transite sheeting were deposited in the $\mathrm{S}$ landfill. Transite sheeting contains 
asbestos. The cooling tower fill deposited in the landfill contained vinyl chloride, asbestos and organics. Hazardous fill provided an extra 2.5 tons per year. The wood used for the cooling tower contained arsenic and pentachlorophenate, which prevents fungus growth. The wood accounted for 0.5 ton per year of weight. A percent breakdown of materials disposed at the landfill also was provided in the report. Approximately 42 percent of materials were cardboard, while 35 percent of materials were paper. Only 13 percent of the actual material going to the landfill was characterized as garbage, while small wood pieces and miscellaneous items accounted for the remaining 10 percent.

Notice of violation was given to the Plant Services Department in 2005. The violations included failure to characterize waste found in newly discovered solid waste management units, and failure to make a determination as to the hazardous or nonhazardous character of wastes deposited in the S\&T landfills.

\section{Principal Contaminants}

\section{Trichloroethylene}

Trichloroethylene (TCE) is a blue or colorless organic liquid. TCE has a distinct chloroform-like odor. Trade names and synonyms include Benzinol, Lethurin, Philex and Vitran. The TCE EPA hazardous waste number is U228, and the Hazardous Substance Data Bank code for TCE is 133(ASTDR, p.182). TCE is used commonly to degrease fabricated metal parts and also in some textiles. TCE can be used also in dry cleaning solvents and a refrigerant/heat exchange liquid. The Safe Drinking Water Act sets the Maximum Contaminant Level for TCE in source water at five parts per billion (ppb). (NPDWR) 
A toxic release inventory conducted between 1987 and 1993 shows Pennsylvania releasing the most TCE into water and land with 33,450 pounds per year. Most of the contaminant released into the water comes from industrial organics industry, releasing 27,708 pounds per year. The steel pipe/tube industry pollutes the land with TCE, at a total of 39,288 pounds per year. The car parts, plating, and wool fabric industries also contributed to the contamination of the land with $19,920,20,100$, and 18,081 pounds, respectively. (NPDWR)

TCE is classified as a highly volatile compound, with vapor pressure of $69.0 \mathrm{~mm} \mathrm{Hg}$ at 25 degrees Celsius. TCE also is denser than water, having a specific gravity of 1.464. Air-born TCE has a residence time of 5-7 days, and degrades to phosgene, dichloroacetyl chloride, and formyl chloride. (ATSDR, p.182-184)

The $\mathrm{LC}_{50}$ is the measure of an instantaneous lethal dose to laboratory animals. The dose amount will result in 50 percent death of the population of laboratory animals within four hours after dosing. Siegel (1971) reported the $\mathrm{LC}_{50}$ dose for TCE at 12,500ppm. Kylin (1962) studied mice exposed to four hours of TCE at a concentration of 6400ppm. A 20 percent death rate occurred. Most deaths were caused from depression of the central nervous system. Prendergast (1967) reported laboratory animals have survived doses from 35ppm for 90 days up to 700ppm for 6 weeks. TCE also causes respiratory problems when victims are exposed through inhalation. Villas (1991) reported that when victims are exposed to 500ppm for 30 minutes, Clara cells in the bronchial tree showed vacuole formation and endoplasmic reticulum dilation. In a study by Windemuller and Ettema (1978), 15 males showed no adverse effects from exposure of 200ppm for 2.5 hours. Other reports from Milby, Sidorin, Bell and Smith have shown adverse reactions to exposure to TCE. (ATSDR, p. 11-19) 
Since TCE is denser than water, it is classified as a dense nonaqueous phase liquid, better known as a DNAPL. A DNAPL solution, such as TCE, tends to travel along water channels within the subsurface until it meets an impervious obstacle. The impervious obstacles that TCE encounter at PGDP are thin clay lenses in the UCRS and in the bottom of the RGA.

\section{$\underline{\text { Technetium-99 }}$}

Technetium-99 (TC-99) occurs naturally in very small amounts in the earth's crust. TC-99 is mostly made artificially during enrichment of uranium and plutonium for nuclear reactors. TC-99 was first produced from neutron or deuteron bombardment of molybdenum sheets. TC-99 also is produced by spontaneous fission of uranium, which occurs in atmospheric nuclear weapons tests. (Peacock 1966)

The main source of TC-99 is from fission product wastes. The yield percent for technetium 99 from thermonuclear fission of uranium 235 is 6.06 percent (Till 1984). In a report with data from 1975 to 1982, the Portsmouth, Ohio plant in 1977 released $31 \mathrm{Ci}$ into water that year (Union Carbide Corp. 1979). Oak Ridge recorded the largest amount of Technetium released into air with $6.8 \mathrm{Ci}$ in 1976 (Union Carbide Corp. 1977).

TC-99, like many radioactive elements, exists as different isotopes. The most common isotope of technetium, TC-99m, is used in the medical field. By injecting technetium into the body, it is possible to produce images from certain organs in the body. (For Example, Figure 20.1 in Ebbing's General Chemistry book shows an image of the entire body made using TC-99m (Ebbing, p.836).) The half-life of TC-99m is approximately 6 hours. The half-life for TC-99, like at PGDP, is 212,000 years. 


\section{E. Other Potential Contaminants: Landfill Leachate Chemicals and Toxins}

A number of chemicals, including potentially toxic compounds and elements, are present typically in landfill leachate. The presence of such chemicals in groundwater under the S\&T landfills would indicate the landfills were possible sources for contaminatnts such as TCE and TC-99. Among the elements found in landfill leachate are cadmium, iron, lead, and zinc (Tchobanoglous et al 1993, p.419). Various chlorides also are commonly found at significant concentrations in landfill leachate. Leachate also typically shows high chemical oxygen demand values (Tchobanoglous et al 1993, p.418).

\section{$\underline{\text { Cadmium }}$}

Cadmium is a naturally occurring element present in the earth's crust. Cadmium cannot exist in the environment in a pure form; it must bind with oxygen, chlorine or sulfur. Cadmium is dangerous because it is not odiferous and is readily soluble in water. Release of the toxin is estimated at 4,000 to 13,000 tons per year in the United States. Cadmium is the by-product of production of metals such as zinc, lead, and copper. Cadmium is found in batteries, some metal alloys, and metal coatings. (ATSDR)

Cadmium seems to show the most potential for problems through inhalation exposure. Accidental acute exposure by inhalation has been recorded. Typical symptoms do not occur until days later, when severe pulmonary edema and chemical pneumonitis cause death (Beton et al, 1966). Measurements of concentrations where death has occurred have ranged from $1.5 \mu \mathrm{g} / \mathrm{g}$ of wet lung tissue to $4.7 \mu \mathrm{g} / \mathrm{g}$. (ATSDR)

\section{$\underline{\text { Chlorides }}$}

Chlorine is the most important and widely distributed halogen in natural water (Hem, p.170). Chlorine is present in various types of rocks, although in low concentrations. 
Chlorine is typically present as the chloride ion, $\mathrm{Cl}^{-}$. Over 75 percent of the total amount of chlorine is present in the earth's crust. Rainwater around the ocean falls with a concentration around $1 \mathrm{mg} / \mathrm{L}$.

Chloride ions do not enter into oxidation or reduction reactions and are not significantly adsorbed on mineral surfaces. Kaufman and Orlob (1956) found that chloride ions move with water through most soils tested. Landfills greater than 10 years old have chloride concentrations ranging from $100 \mathrm{mg} / \mathrm{L}$ to $400 \mathrm{mg} / \mathrm{L}$ (Tchobanoglous et al., p.418). $\underline{\text { Iron }}$

EPA classifies iron as a secondary contaminant, setting the standard to $0.3 \mathrm{mg} / \mathrm{L}$ maximum contaminant level. When the iron enters the groundwater, it forms ferrous iron II. Iron II does not cause a problem, but it does form iron III. Iron III reacts with oxygen or bacteria and forms insoluble hydroxides. These cause blockages in pipes and pumps, and eventually attract bacteria. The bacteria cause odor and blockage problems also (Lenntech). Landfills over 10 years old have iron concentrations ranging from $20 \mathrm{mg} / \mathrm{L}$ to $200 \mathrm{mg} / \mathrm{L}$ (Tchobanoglous et al., p.418).

$\underline{\text { Lead }}$

Lead is a naturally occurring element in the Earth's crust. Lead normally does not occur in pure form; rather it stabilizes with two or more elements to form lead compounds. Lead presents itself in typical everyday objects such as batteries, pipes, and munitions. Before the 1980's lead also was found in paints and ceramic glazes. Lead has been banned in gasoline. (ATSDR)

When lead is released into the ground, it adheres to soil particles. It is released only when it is exposed to acidic water. Lead enters the human body through ingestion of lead- 
ridden foods or lead-contaminated water. Water can be contaminated by lead though groundwater contamination or lead pipes existing in the structure. Lead is also found in cigarettes, lead solder, and high exposure near busy highways. About 99 percent of the lead taken in by an adult leaves the body, while only 32 percent leaves children. (ATSDR)

Lead attacks the body in the same way whether it is ingested or inhaled. Lead disrupts the nervous system by reducing its effectiveness, causing weakness in fingers, hands, and toes. High exposure causes fatal brain and kidney damage. Lead can also cause reduced sperm production in males and miscarriages in females. (ATSDR)

$\underline{\text { Zinc }}$

Zinc is one of the most abundant naturally occurring metals. Zinc is present in almost all foods. Zinc commonly protects steel from corrosion when steel is galvanized. Zinc is used in products ranging from shampoos to sun block. Zinc usually adheres to soil particles and is insoluble in water, but some types of zinc compounds have the ability to transfer to the groundwater. Fish also absorb zinc. (ATSDR)

The recommended daily allowance of zinc for men is $11 \mathrm{mg} / \mathrm{day}$, while women are allowed $8 \mathrm{mg} / \mathrm{day}$. Adverse reactions for exposure ten to fifteen times RDA such as vomiting, nausea, and stomach cramps occur. Health effects such as reduced HDL cholesterol and pancreas damage occur when subjects are exposed to zinc over a long period of time. (ATSDR)

\section{Chemical Oxygen Demand}

Chemical Oxygen Demand (COD) is the measurement of oxygen required to oxidize wastes chemically. COD is calculated when compounds present in a water sample resist degradation by biologic activity. Typical COD values for landfills older than 10 years range 
from $100 \mathrm{mg} / \mathrm{L}$ to $500 \mathrm{mg} / \mathrm{L}$ (Tchobanoglous et al., p.418). The test involves mixing known quantities of sulfuric acid reagent containing silver sulfate, and potassium dichromate, with the sample. The mixture is vaporized and condensed for two hours, with condenser attached. The following chemical equation shows the process.

$$
\text { Organic_Matter }+\mathrm{Cr}_{2} \mathrm{O}_{7}{ }^{2-}+\mathrm{H}^{+} \stackrel{\text { heat }+\mathrm{AG}^{+}}{\longrightarrow} \mathrm{CO}_{2}+\mathrm{H}_{2} \mathrm{O}+2 \mathrm{Cr}^{3+}
$$

The amount of excess dichromate is measured by titration with ferrous ammonium sulfate. A sample of distilled water is tested to repeat the procedure to check for errors caused by organic matter present in the reagents. The COD can be calculated using Equation 2. (Viessman, Jr. and Hammer 1998)

$$
C O D=\frac{(a-b)\left[\left(\text { normality_of_Fe }{ }_{-}\left(\mathrm{NH}_{4}\right)_{2}\left(\mathrm{SO}_{4}\right)_{2}\right] 8000\right.}{V}
$$

where

$$
\begin{aligned}
& \mathrm{COD}=\text { chemical oxygen demand, } \mathrm{mg} / \mathrm{l} \\
& \mathrm{a}=\text { amount of ferrous ammonium sulfate titrant added to blank, } \mathrm{ml} \\
& \mathrm{b}=\text { amount of titrant added to sample, } \mathrm{ml} \\
& \mathrm{V}=\text { volume of sample }
\end{aligned}
$$

Section II provided site information for PGDP. The geology of the site provided information about the potential paths by which the contaminants can disperse. The groundwater flow direction from the model is north-northeast. The primary contaminants present very serious health concerns for people. The leachate chemicals and toxins provide secondary checks for landfill leakage. Section III analyzes the data in order to investigate the landfill problem. Only data for the monitoring wells provided within the investigation area were analyzed. Bechtel-Jacobs Company LLC provided the data via an FTP site. 


\section{ANALYSIS OF DATA}

Groundwater chemical analysis samples for the site were collected by different companies responsible for the site at different times. Each sample had a full analysis performed. TCE concentrations were reported with detection limits. Technetium-99 activities included detection limits, along with an error inherent in the radiation measurement technique. Sample data sheets are shown in Appendix I.

\section{Data Sorting Method}

Each measurement value of TCE was accompanied by its detection limit. The detection limit is the lowest possible value that the test method allows. If a concentration value was at or below the detection limit, then the concentration value could be taken to be the detection limit, or it could have been discarded. A problem occurs with discarding data because the test did detect some source of contaminant. By excluding the data, any statistical analysis program will perceive that value as zero, instead of the possible detection limit. As the detection limit increases, the error in excluding the data increases. Also, as the concentration value approaches the detection limit, the data results can be skewed due to the exclusion. The dilemma caused by excluding data could have been serious for plots based on statistics. The patterns of the derived contaminant plumes would have been affected by the plot of zero values or the detection limit. Therefore, all data values were included, whether they were above, at, or below the detection limit. 


\section{A. Parameter Analysis versus Time}

\section{$\underline{\text { Well Groups }}$}

Assuming the groundwater flow model developed was correct, three groups of wells were chosen. Each group served its own purpose to investigate possible transport paths for the contaminants.

\section{Group 1}

The first group of wells was MW263, MW179, and MW264. Figure 7 shows the well locations in reference to the landfills. This group of wells is located approximately the same distance north of the landfills. Since the groundwater flow is generally assumed to be northnortheast, these wells should show any transport of contaminants from the landfill.

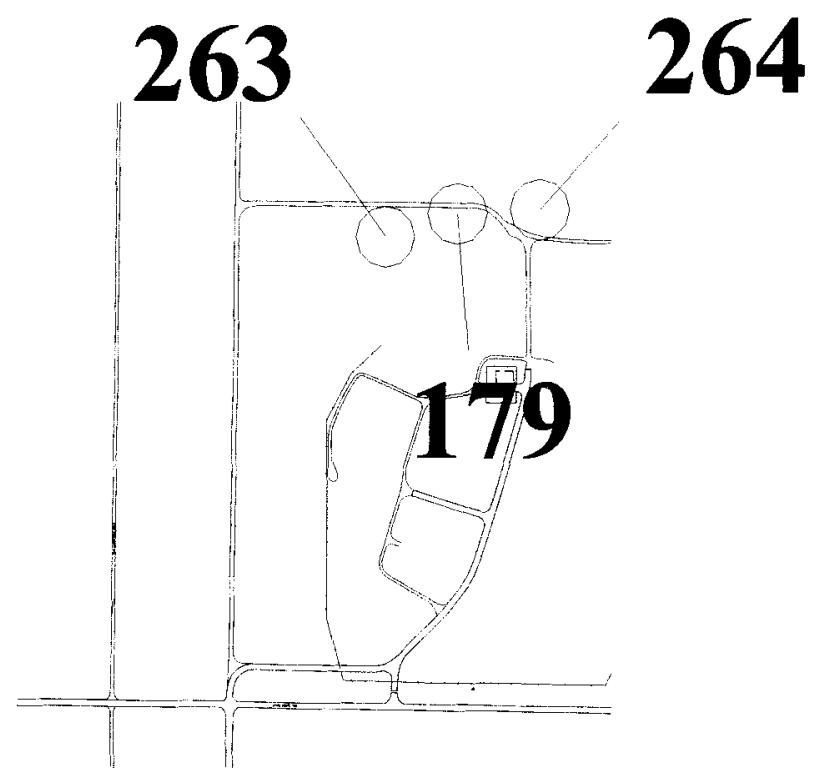

Figure 7 - Well Group 1

\section{Trichloroethylene Plots-Group 1}

Figure 8 shows a plot of the concentration of TCE versus time at wells 179, 263, and 264. If the landfills are sources of TCE, then TCE concentrations in each MW should peak 
at approximately the same time. MW263 records the greatest value for the well group in July 2001 at $23 \mu \mathrm{g} / \mathrm{L}$. MW179 also peaks during July 2001 at $9 \mu \mathrm{g} / \mathrm{L}$. During July 2001, MW 264 recorded a concentration of $4 \mu \mathrm{g} / \mathrm{L}$. MW264 peaks during October 2000 at $6 \mu \mathrm{g} / \mathrm{L}$. MW179 and MW264 show a considerable difference from MW263 during July 2001. If the landfills are sources of TCE, then the concentrations of the well group should be very similar. The well group data do not show any hard evidence of a possible TCE leak from the landfills.

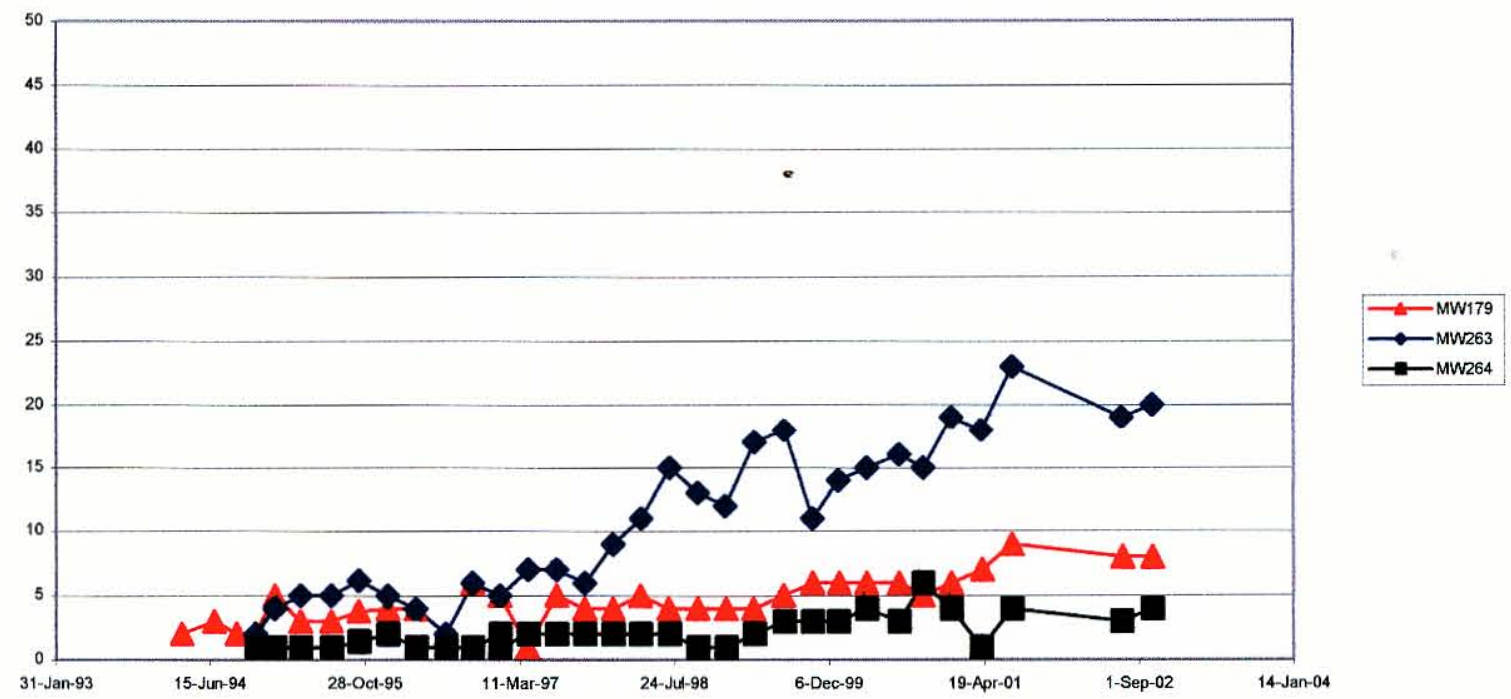

Figure 8 - TCE Well Group 1 Plot of Concentration versus Time

Technetium-99 Plots-Group 1

Figure 9 shows a plot of the concentration of TC-99 versus time in group \#1 wells. MW263 and MW264 show no relative increase during the period. The highest value for MW263 occurs on October 1999; the concentration of TC-99 was recorded at $48.3 \mathrm{pCi} / \mathrm{L}$. MW264 shows a peak value of $121 \mathrm{pCi} / \mathrm{L}$ in November 1994 . MW179 shows two distinct peaks. The first peak occurs in July 1998, while the other larger peak occurs in July 2001. The concentration values are $451.8 \mathrm{pCi} / \mathrm{L}$ and $506 \mathrm{pCi} / \mathrm{L}$, respectively. According to the 
location of the wells, data from MW263 and MW 264 should mimic these two peaks. The graph shows good evidence that the landfills are not sources of TC-99.

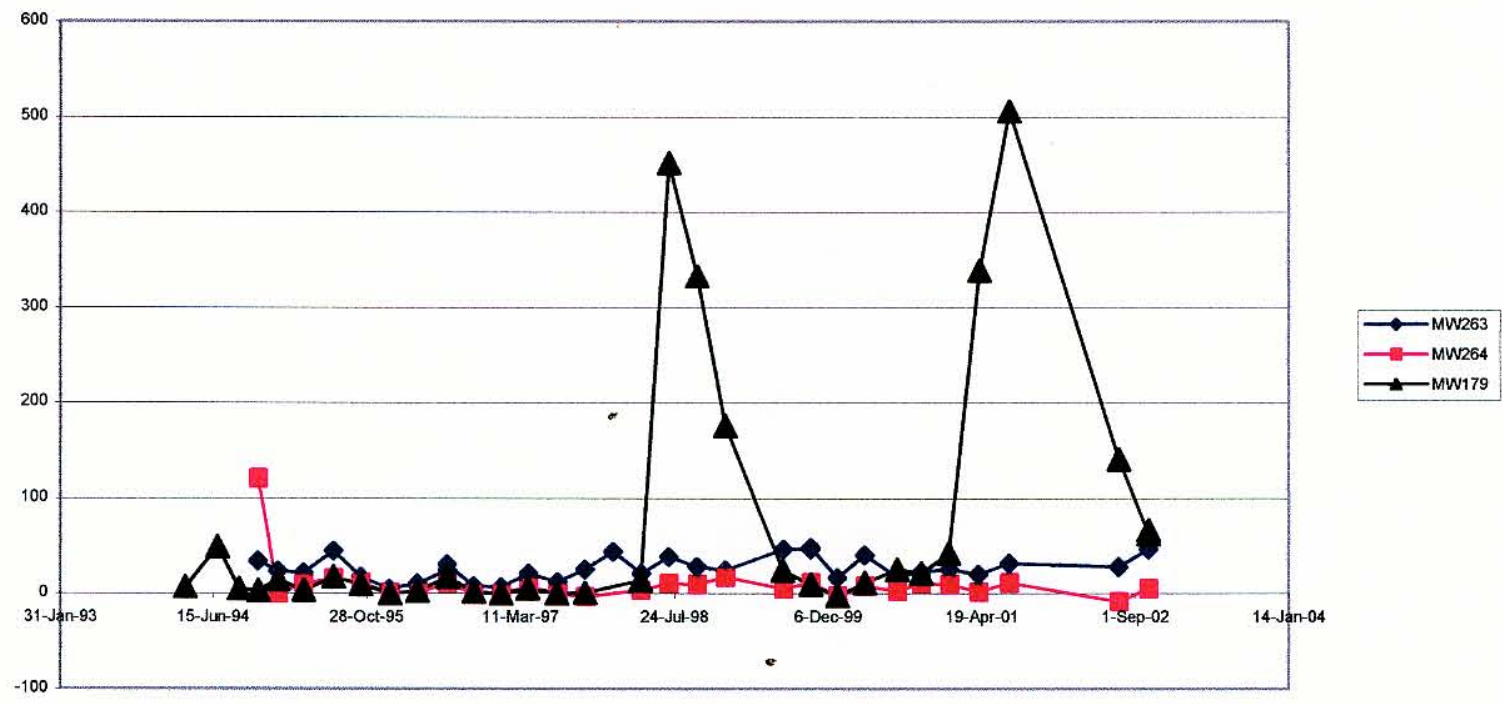

Group 2

Figure 9 - TC-99 Well Group 1 Plot Activity versus Time

The second group of wells is MW353, MW267, MW179, and MW273. The wells are plotted in Figure 10, showing their orientation to the landfills. These monitoring wells are located along the assumed groundwater flow direction north-northeast. Each well bottoms in the middle of the RGA. 


\section{3}

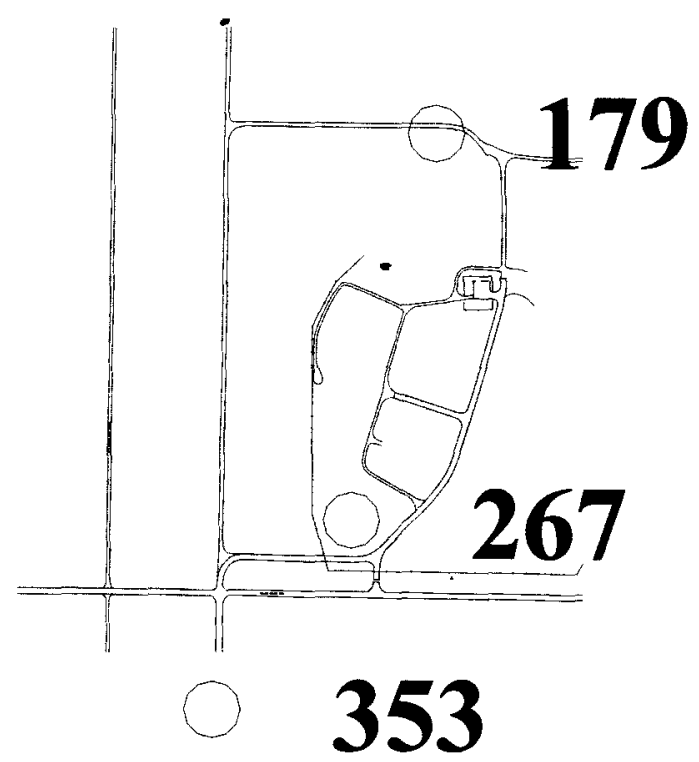

Figure $10-$ Well Group 2

Trichloroethylene Plots-Group 2

The TCE concentrations in the well group were plotted versus time in Figure 11. MW353 and MW267 show detection limit readings throughout the sampled time. MW179 data show considerable fluctuation and increase. The concentration fluctuates between 1 $\mu \mathrm{g} / \mathrm{L}$ and $9 \mu \mathrm{g} / \mathrm{L}$ during the study period. MW 273 should mimic these fluctuations, if TCE is coming from the landfills because of the location of MW 273 down gradient from MW 179. MW273 shows no fluctuations, staying at the detection limit during the study time. Data from this well group are inconclusive. 


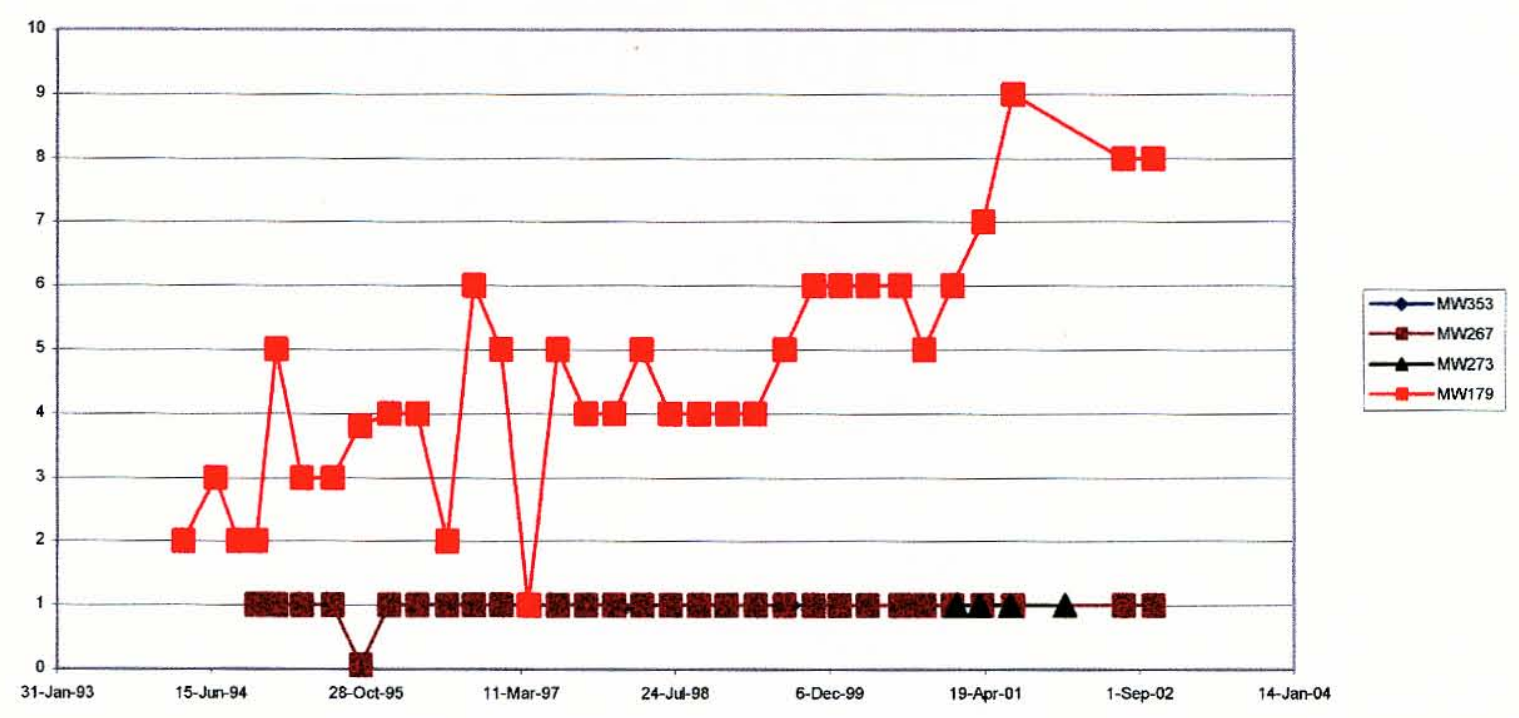

Figure 11 - TCE Well Group 2 Plot of Concentration versus Time

Technetium-99 Plots-Group 2

Technetium-99 activities are plotted versus time in Figure 12 for Group 2 wells. Data from MW353 and MW267 would show any TC-99 that may enter the study area through contamination sources located south of the landfills. MW267 shows no TC-99 moving into the area. MW353 shows some signs of a contaminant moving into the area. MW179 data show the same signature twin peak shown in Figure 9, while MW273 data show little activity. If the landfills were a source of contaminant, then a moving peak would be present on the plot as shown by peaks at different times in different wells. With the high activities of TC-99 in MW179 data not showing in MW273 data, it is highly probable that the landfills are not a source of TC-99 contamination.

If a spike on the plot in Figure 12 represents the passage of a slug of contaminant through the RGA, from MW 353 toward MW 179, the data suggest that a slug of TC-99 passed from MW 353 to MW 179 in about 21 months. With the distance between those two 
wells being 2150 feet, it is possible to estimate the rate of contaminant travel as about 3 $\mathrm{ft} /$ day, which is consistent with estimates from groundwater studies done at PGDP.

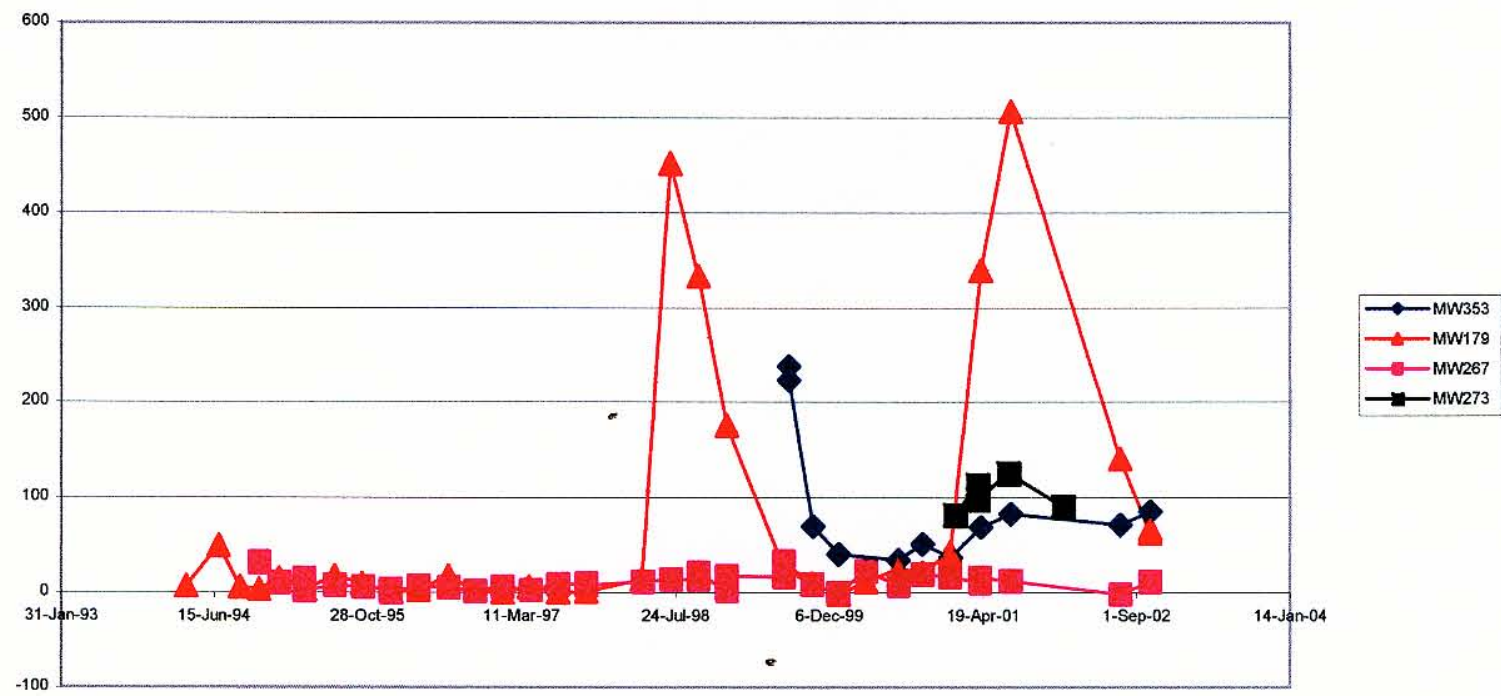

Figure 12 - TC-99 Well Group 2 Plot of Activity versus Time

\section{Group 3}

The third group of wells is MW266, MW275, and MW272, shown in Figure 13. The group also is aligned with the assumed groundwater flow direction. The sampling zones in these wells are located in the lower RGA. 


\section{$\mathbf{2 7 2}$ \\ 275}

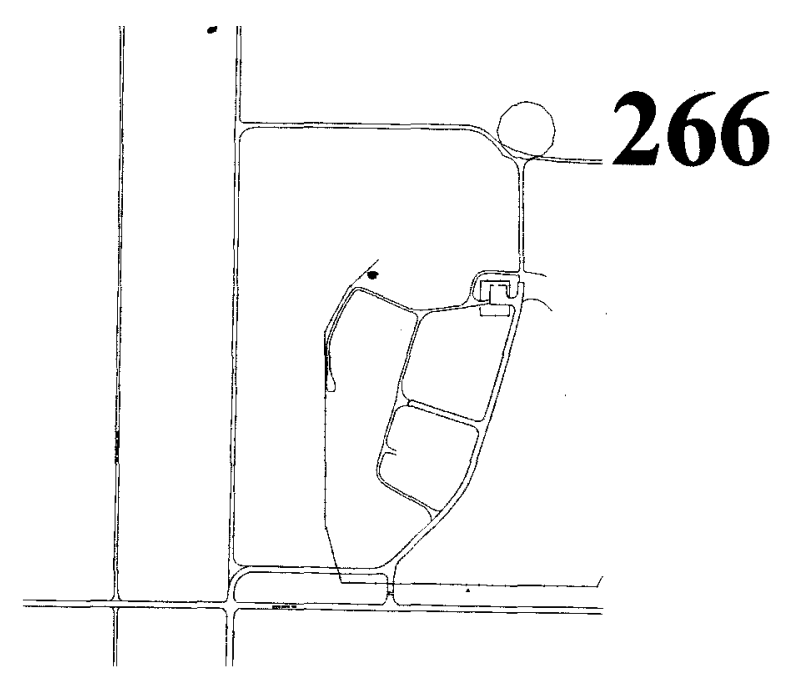

Figure 13 - Well Group 3

Trichloroethylene Plots-Group 3

With TCE being a DNAPL, it is more likely that the contaminant would be transported along the bottom of the RGA. Also, if the landfill is a true source of TCE, then the well cluster data should show some increased concentrations. Figure 14 shows a plot of the well cluster concentrations of TCE versus time. The concentration of TCE increases to a peak concentration of $16 \mu \mathrm{g} / \mathrm{L}$ in April 2001, then decreases. MW275 and MW272 record detection limit concentrations during the study period. Data from MW266 indicate that the landfills could be a source of TCE. However, concentration from MW266 should show on 
MW275 and MW272 if the landfills are a true source, and no such increase is shown.

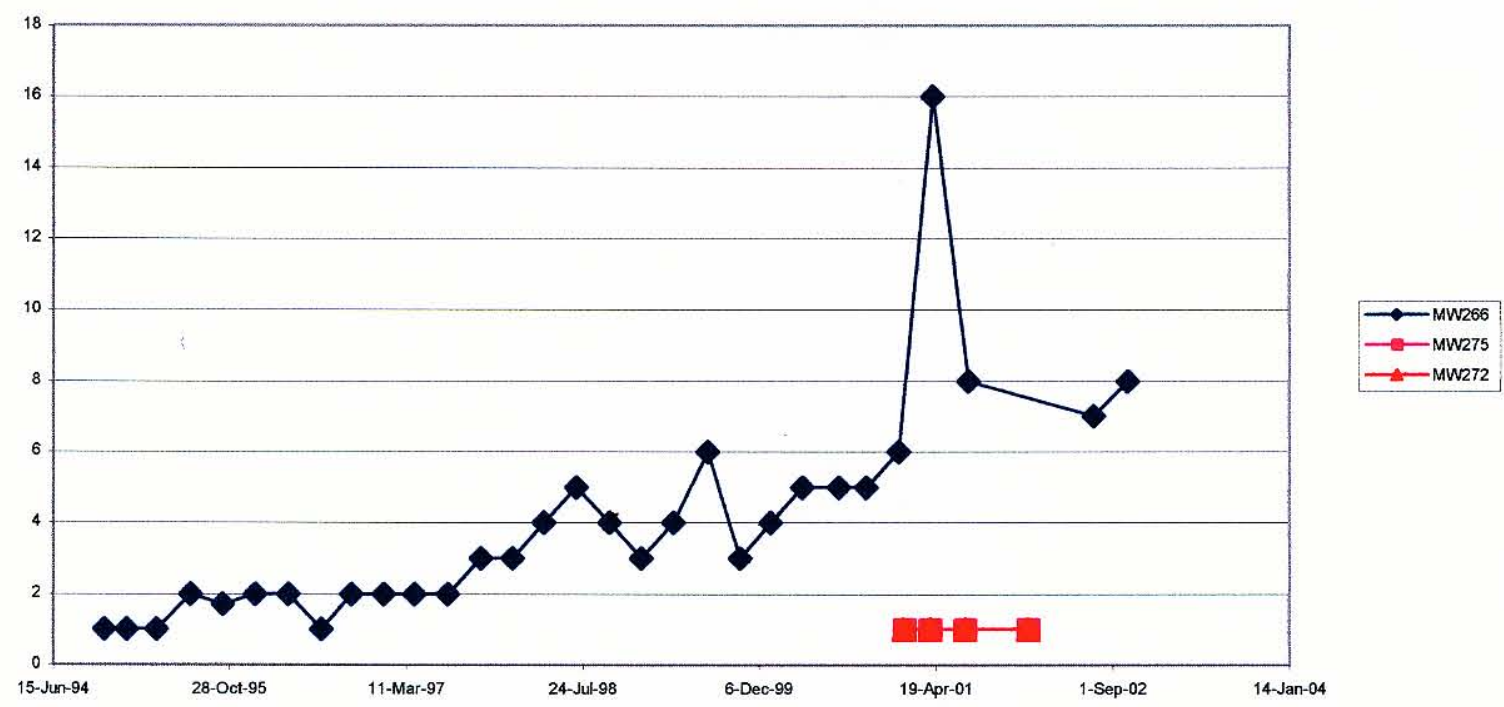

Figure 14 - TCE Well Group 3 Plot Concentration versus Time

Technetium-99 Plots-Group 3

Data from MW266 show the best evidence, in combination with data from MW275 and MW272, that the landfills are not a source of TC-99. MW266 shows a peak activity of $19.6 \mathrm{piC} / \mathrm{L}$ during April 1998, as shown in Figure 15. MW275 shows the highest activity of $231 \mathrm{pCi} / \mathrm{L}$. MW272 also shows high activity of TC-99, increasing to $78.6 \mathrm{pCi} / \mathrm{L}$. If the landfills are a source of TC-99, then MW266 should show the peak values that occur at MW275 and MW272. Without a large activity in the data for MW266, the plot shows strong evidence of no TC-99 leak. 


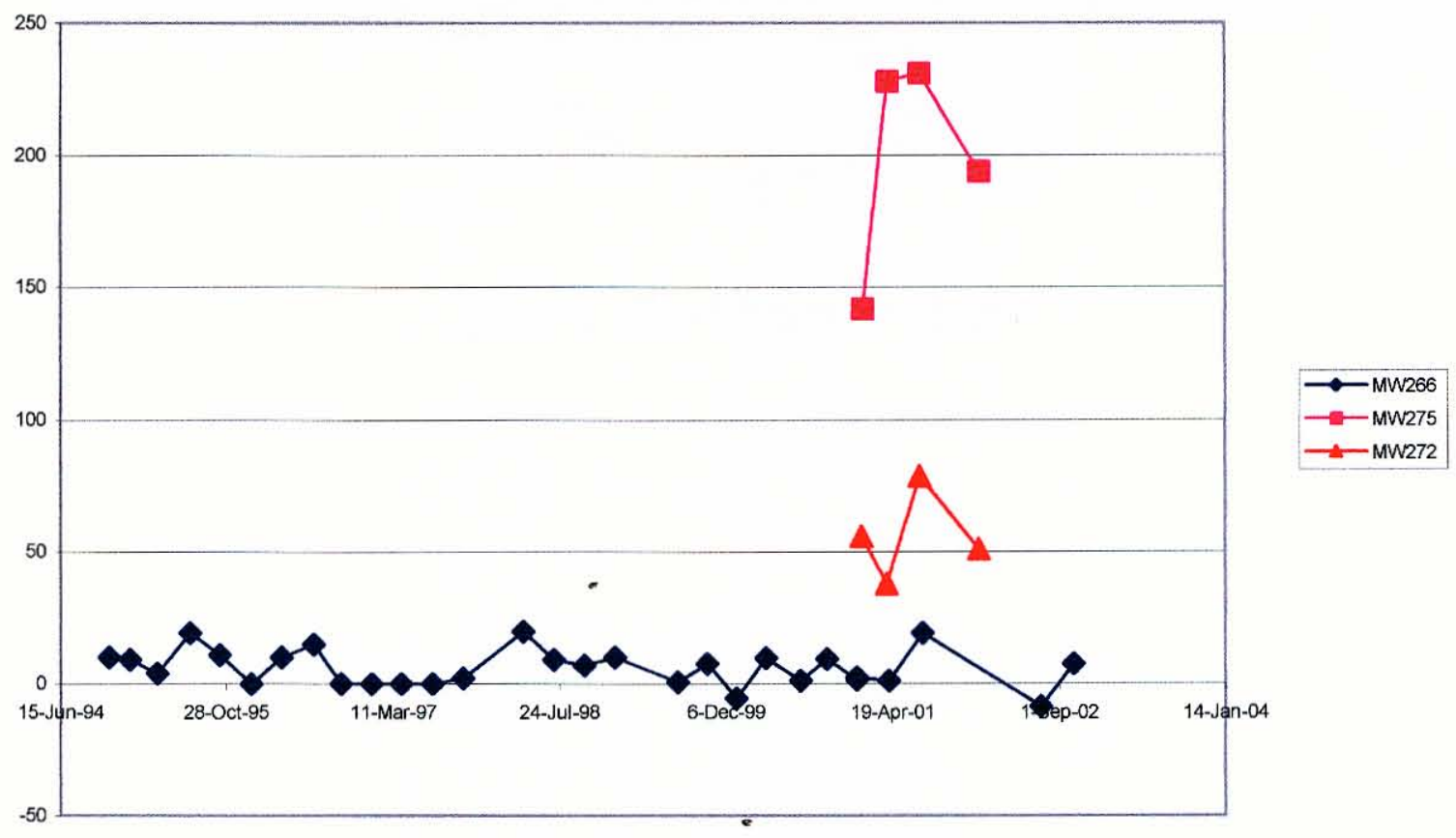

Figure 15 - TC-99 Well Group 3 Plot Activity versus Time

B. Parameter Analysis versus Time and Space

\section{$\underline{\text { Surfer Analysis }}$}

Surfer is a program developed by Golden Software (2002). The program has the ability to plot data at Cartesian coordinates at a particular elevation. The program can be used to plot concentration and activity values. The user-friendly interface allows importing Excel files for easy plotting. In general, the darker the color, the higher the concentration or activity.

\section{Trichloroethylene Plots}

Surfer plots were generated for TCE around the area of the S\&T landfills by year, and by elevation. The years chosen were 1988, 1991, 1994, 1997, 2000, 2001, 2002, and 2003. Figures 16 through 23 show plots for those years. Figure 16, the 1988 plot of the 
concentration of TCE in the RGA, suggests two possible sources of contaminant. The apparent source southeast of the landfills has a higher concentration of TCE than does the apparent source northwest of the landfills. The shape of the southeast "hot spot" is interesting. The plume of contaminant is elongated almost perpendicular to groundwater flow. The northwest hot spot also elongates perpendicular to the groundwater flow. The 1991 plot of TCE concentration, Figure 17, shows the 1988 southwest plume apparently has grown. The size and concentration have increased. The 1988 northeast plume has reduced in size and concentration. The pattern formed by the 1988 and 1991 plots shows the contaminant moving in the east-southeast direction. This direction implies flow perpendicular to the accepted groundwater moderflow directions. Furthermore, the plots of TCE concentration shown in Figures 18 through 23 show an apparent irregular disappearance and reappearance of implied sources of TCE northwest and southeast of the S\&T landfills. All of these plots suggest sources of TCE outside the landfills, with implied movement of TCE perpendicular to the most likely direction of groundwater flow. 


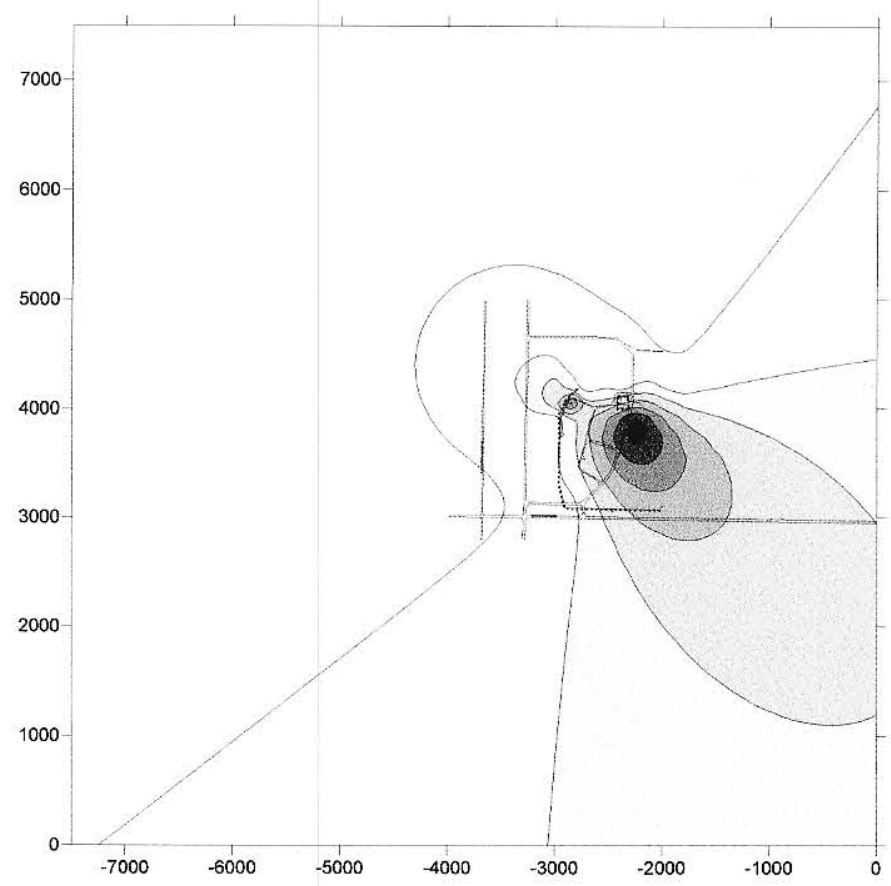

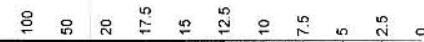

Figure 16 - TCE Surfer Plot 1988

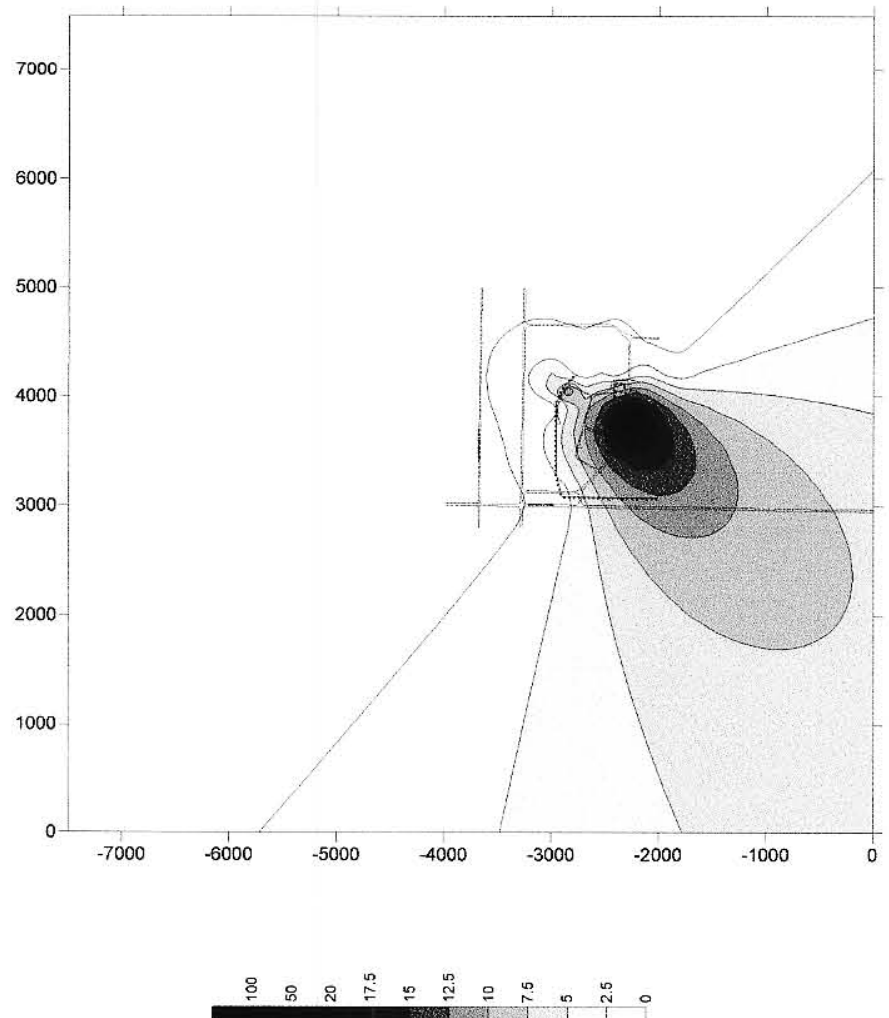

Figure 17 - TCE Surfer Plot 1991 


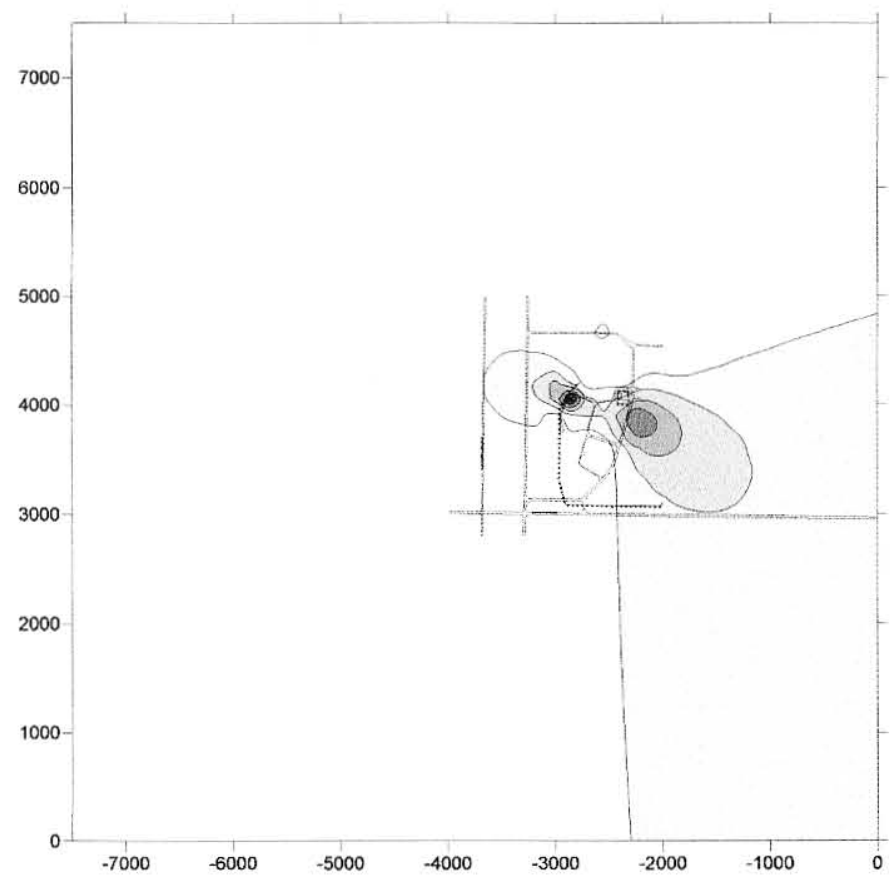

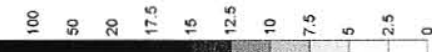

Figure 18 - TCE Surfer Plot 1994

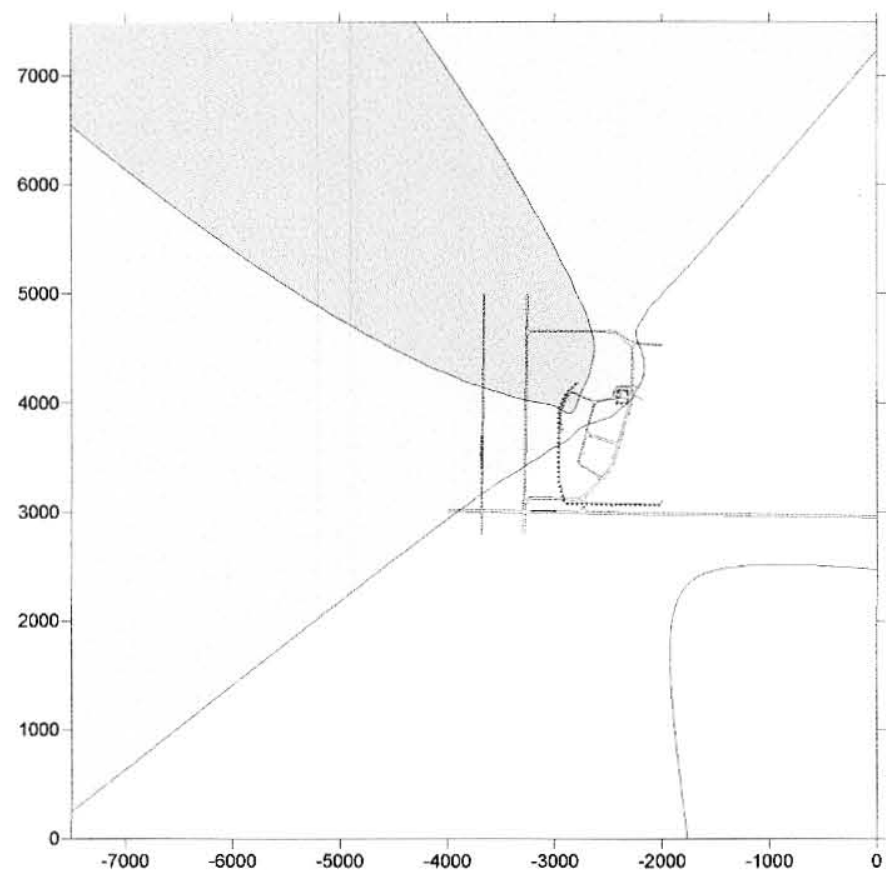

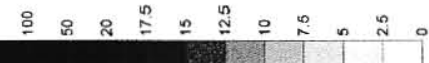

Figure 19 - TCE Surfer Plot 1997 


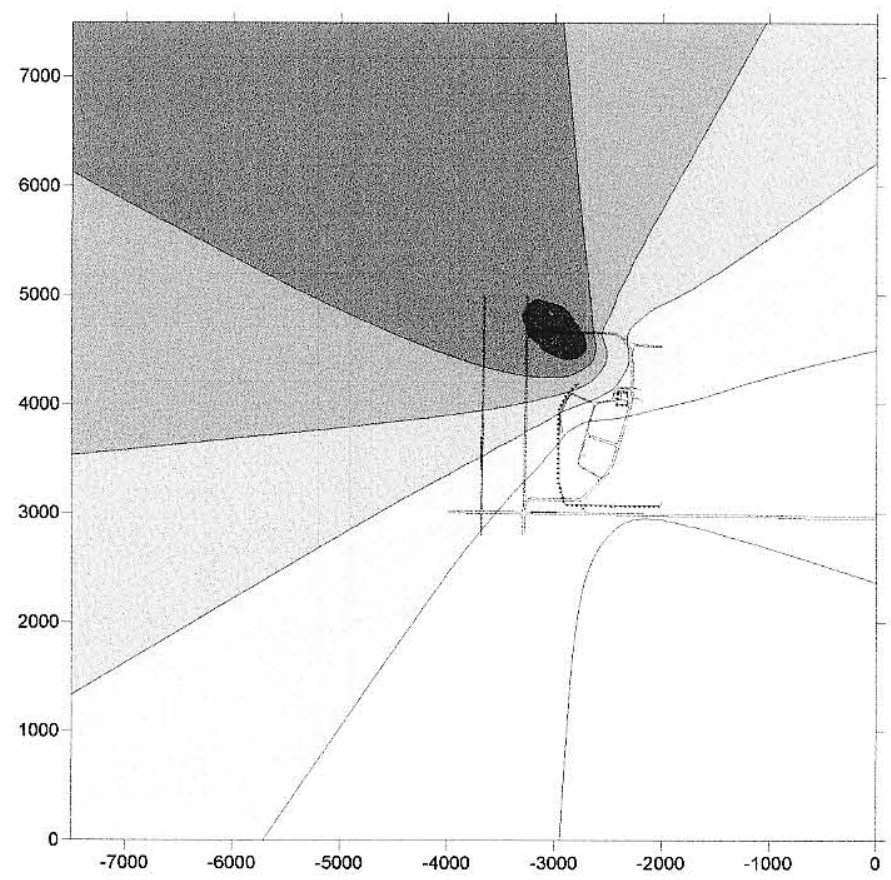

웅ำ

Figure 20 - TCE Surfer Plot 2000

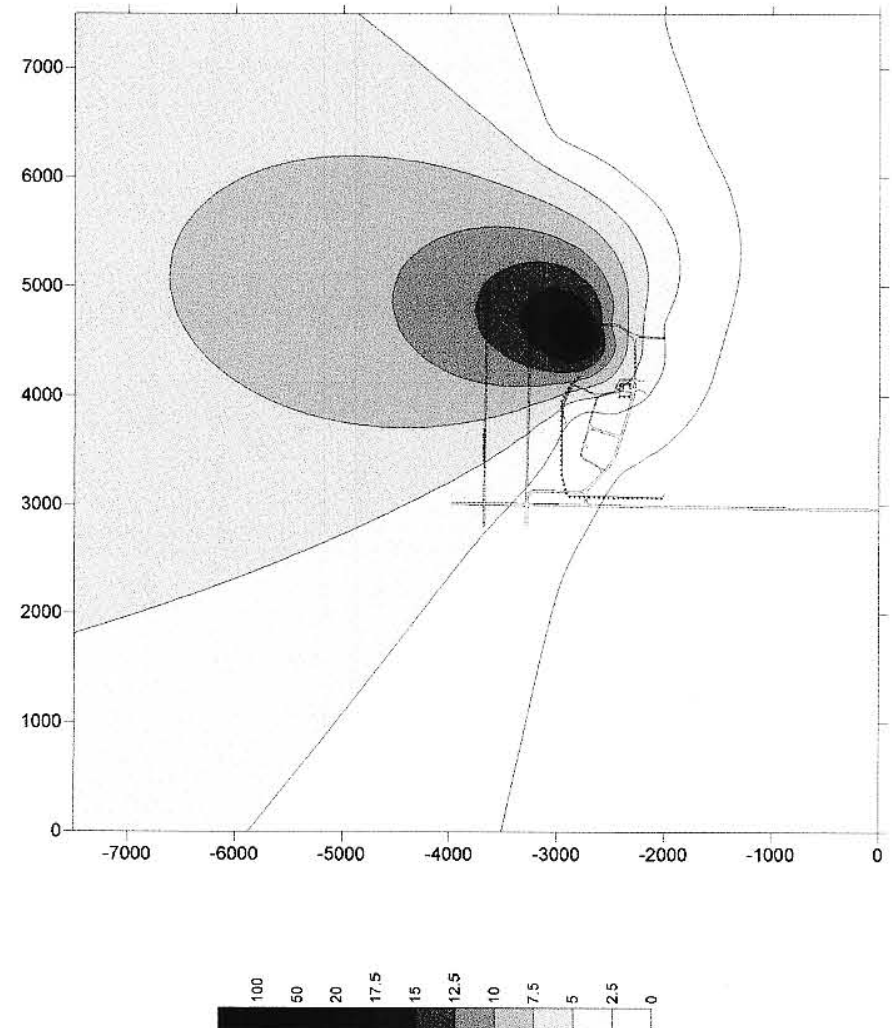

Figure 21 - TCE Surfer Plot 2001 


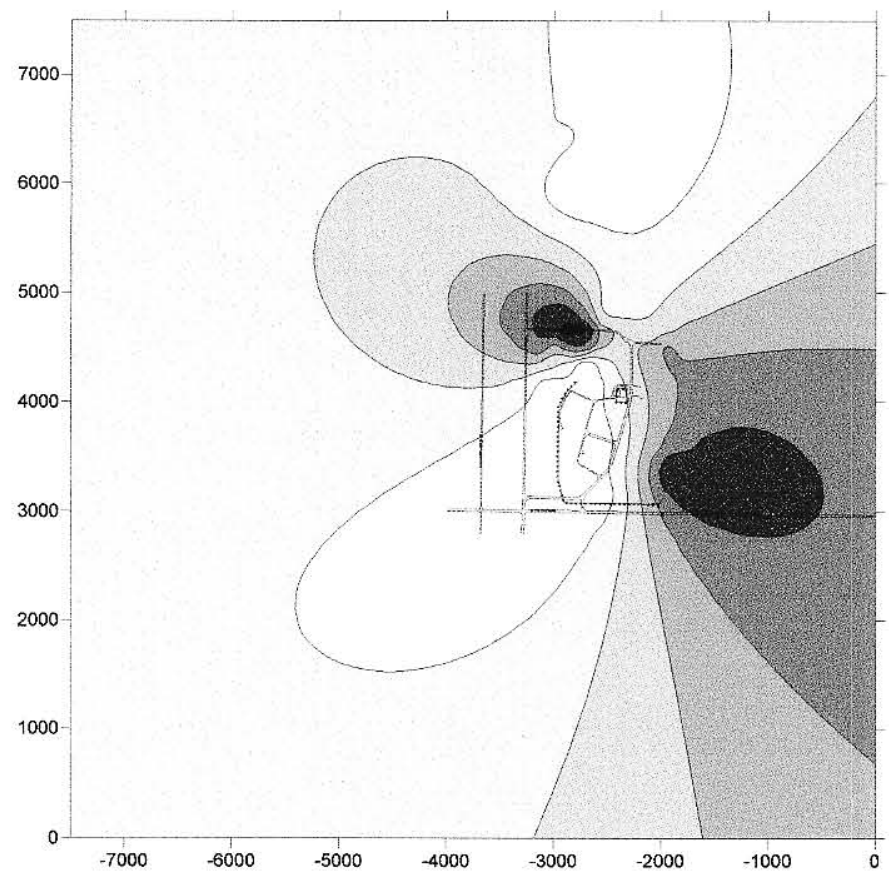

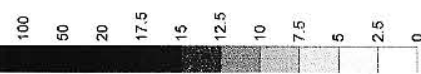

Figure 22 - TCE Surfer Plot 2002

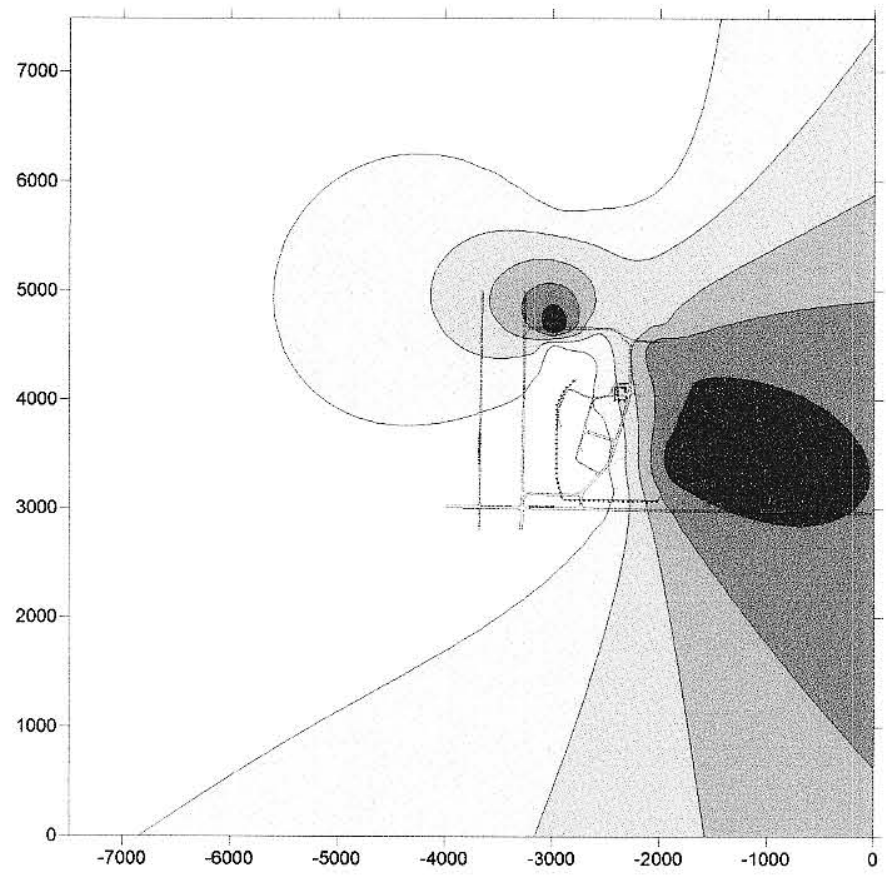

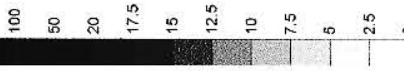

Figure 23 - TCE Surfer Plot 2003 


\section{Technetium-99 Plots}

Figures 24-29 show Surfer plots of TC-99 activities in the RGA, for 1994, 1997, $2000,2001,2002$, and 2003, respectively. The 1994 plot of TC-99 activities, Figure 24, shows two apparent sources, or "hot spots". One hot spot is located to the northeast of the landfills, while the other hot spot is located southwest of the landfills. The 1997 plot, Figure 25 , reveals the disappearance of the two hot spots. The hot spots are replaced by an increased activity of TC-99 from the northeast to the southwest. The 2000 plot, Figure 26, shows the return of the southwest hot spot. The plume formation implies a groundwater flow perpendicular to the accepted groundwater flow direction of north-northeast. The 2001 plot, Figure 27, shows a decrease in activity at the southwest hot spot. The northeast hot spot returns with another hot spot located farther to the northeast. The 2002 plot, Figure 28, shows a reduction of activity around the landfills, with a reduction in activity of the new northernmost hot spot. The 2003 plot, Figure 29, shows a complete site reduction in activity around the landfills. None of the original hot spots are present. The sequence of plots shows no real pattern of activity of TC-99 in the RGA below the landfills. If the landfills were a source of TC-99, then the Surfer plots should show a corresponding plume originating at the landfills. 


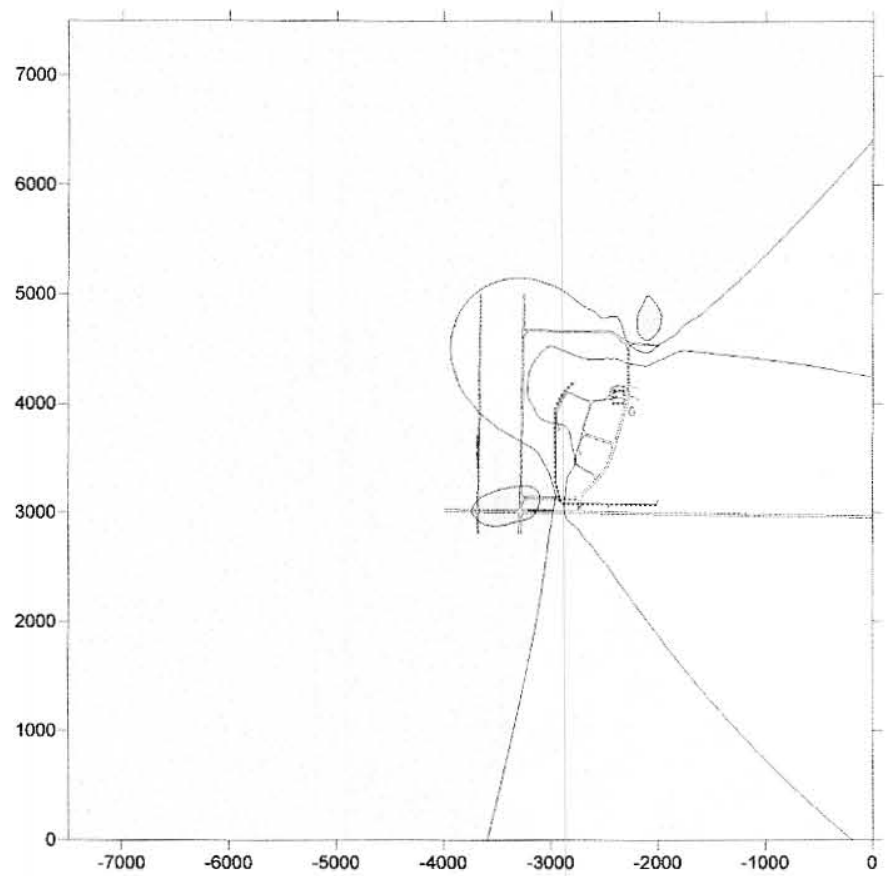

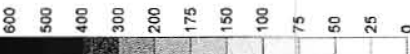

Figure 24 - TC-99 Surfer Plot 1994

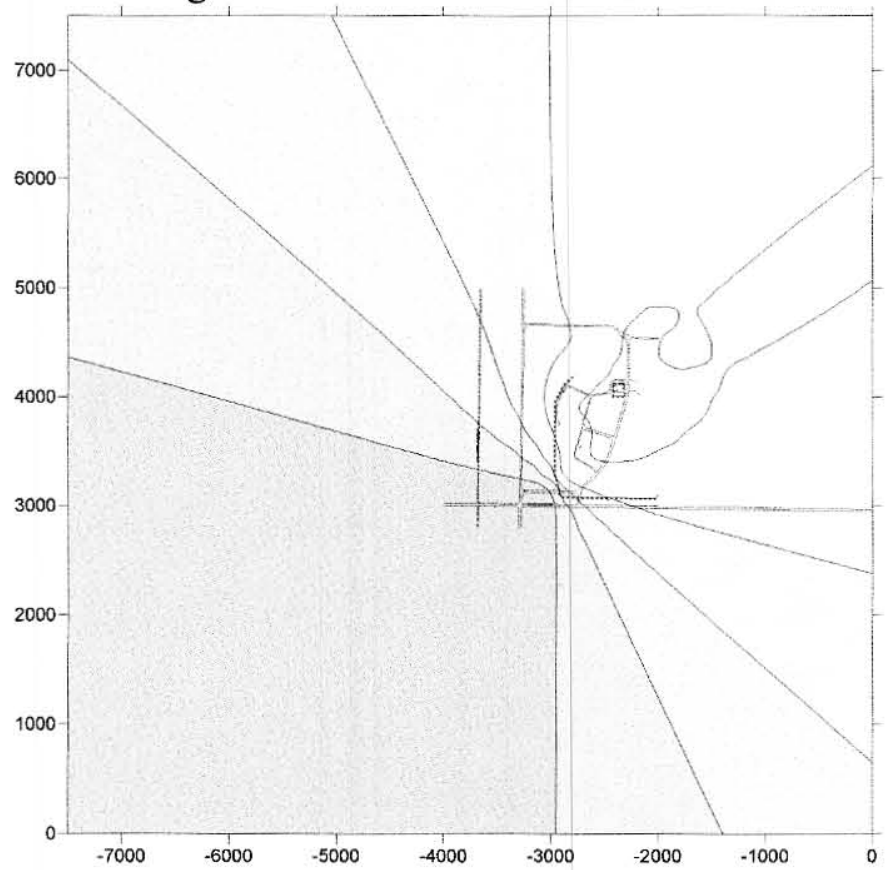

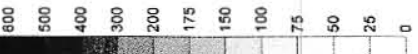

Figure 25 - TC-99 Surfer Plot 1997 


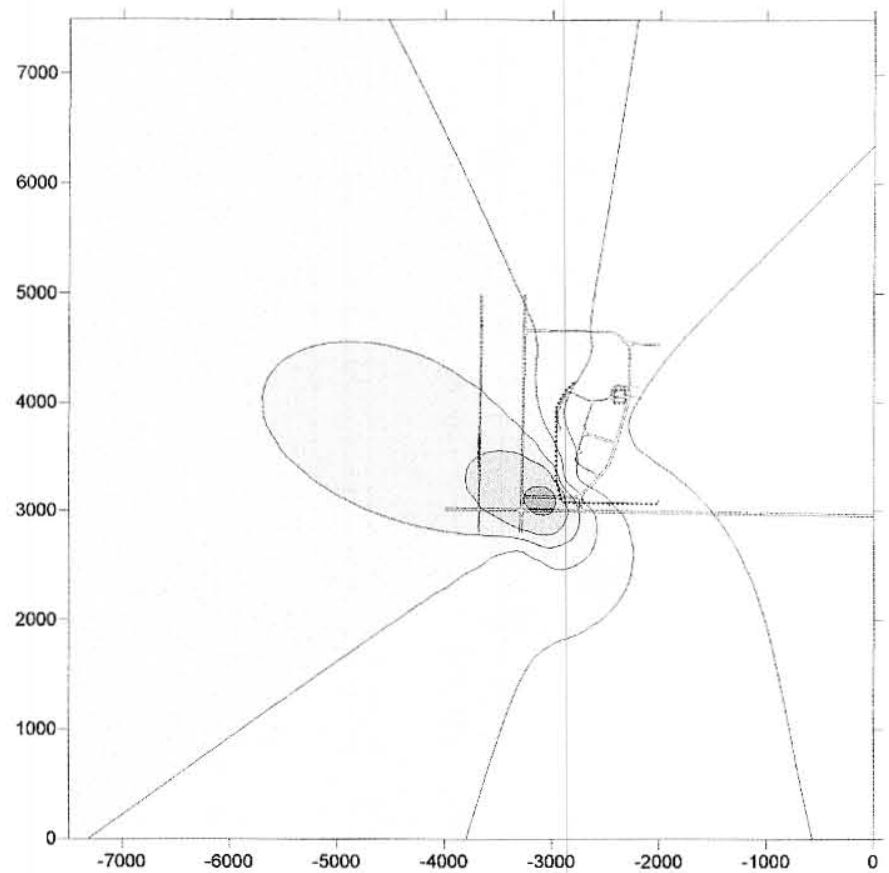

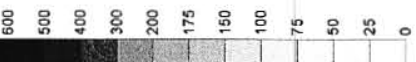

Figure 26 - TC-99 Surfer Plot 2000

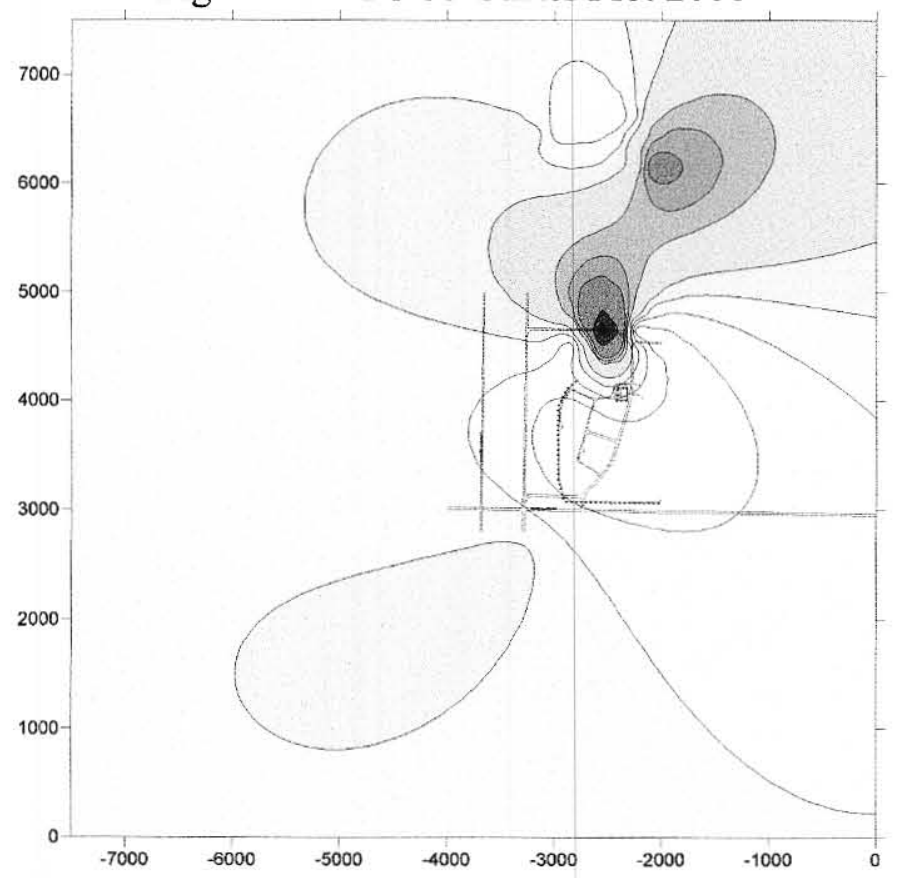

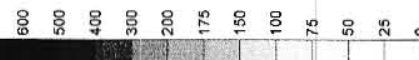

Figure 27 - TC-99 Surfer Plot 2001 


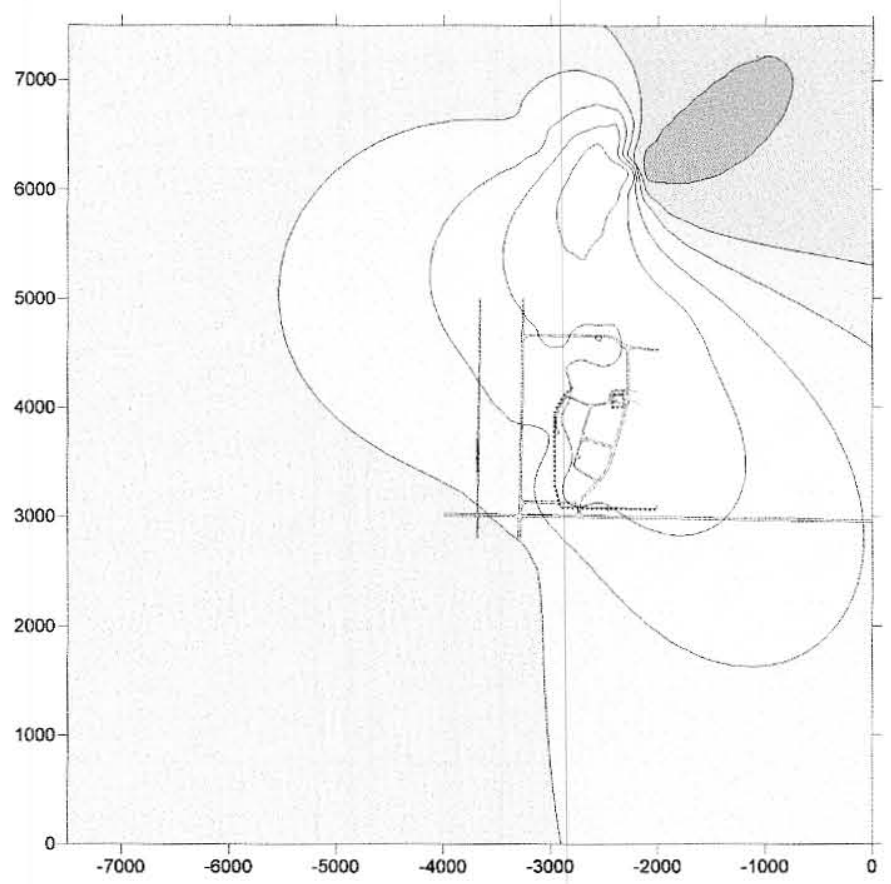

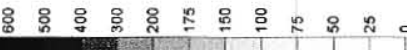

Figure 28 - TC-99 Surfer Plot 2002

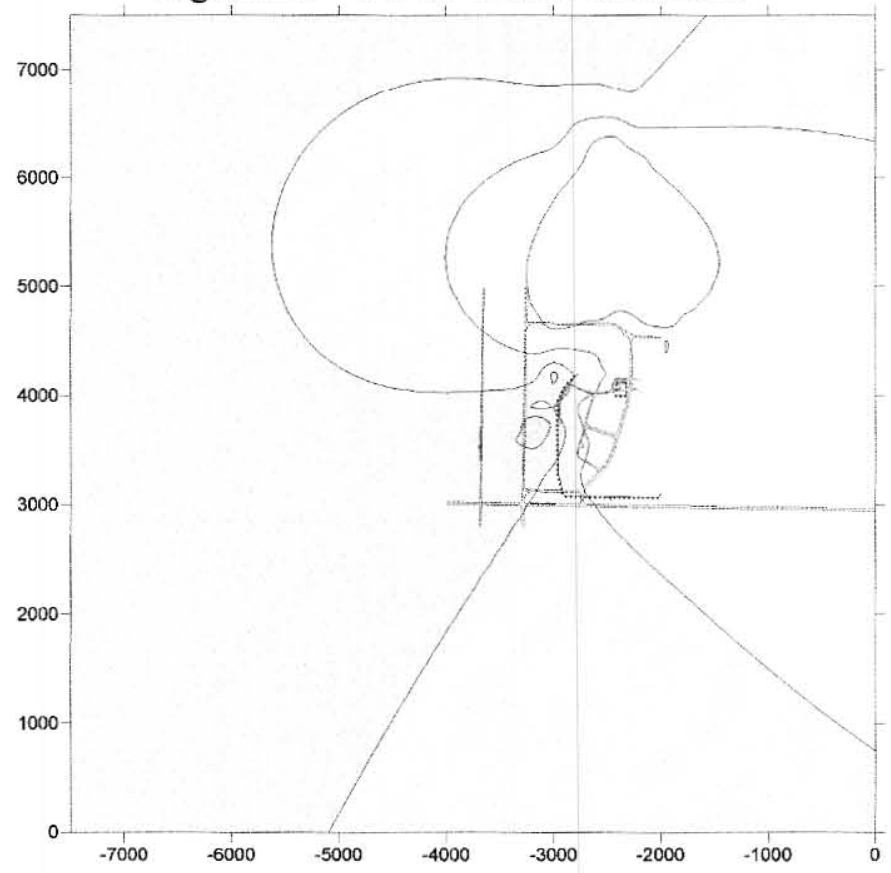

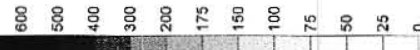

Figure 29 - TC-99 Surfer Plot 2003 


\section{Groundwater Flow Direction Accuracy}

The results from the Surfer plots put in question the accuracy of the groundwater flow model. Surfer plots at different times show plume patterns different from those expected from the assumed north-northeast flow direction. Two wells show some evidence of the north-northeast flow direction. Figure 30 shows the locations of MW179 and MW275. The sampling zone for MW179 is located in the middle depth of the RGA, while the sampling zone for MW275 is located in the lower RGA. When the activity of TC-99 was plotted versus time in Figure 31, the pattern expected from the location of the two wells was found. MW179 shows a distinct peak activity in July 1998. MW275 shows a distinct peak during July 2001. The distance between the wells is 1570 feet, and the time for the contaminant plug to travel is 36 months. Therefore the contaminant plug velocity is $1.5 \mathrm{ft} / \mathrm{day}$. This result agrees with the accepted values of effective porosity, gradient, groundwater flow direction and contaminant transport velocity. 


\section{$\mathbf{2 7 5}$}

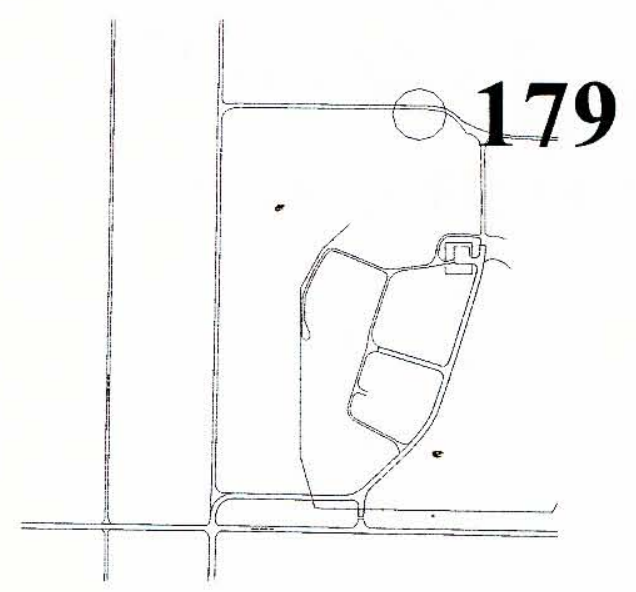

Figure $30-$ MW 179 and MW 275 Location

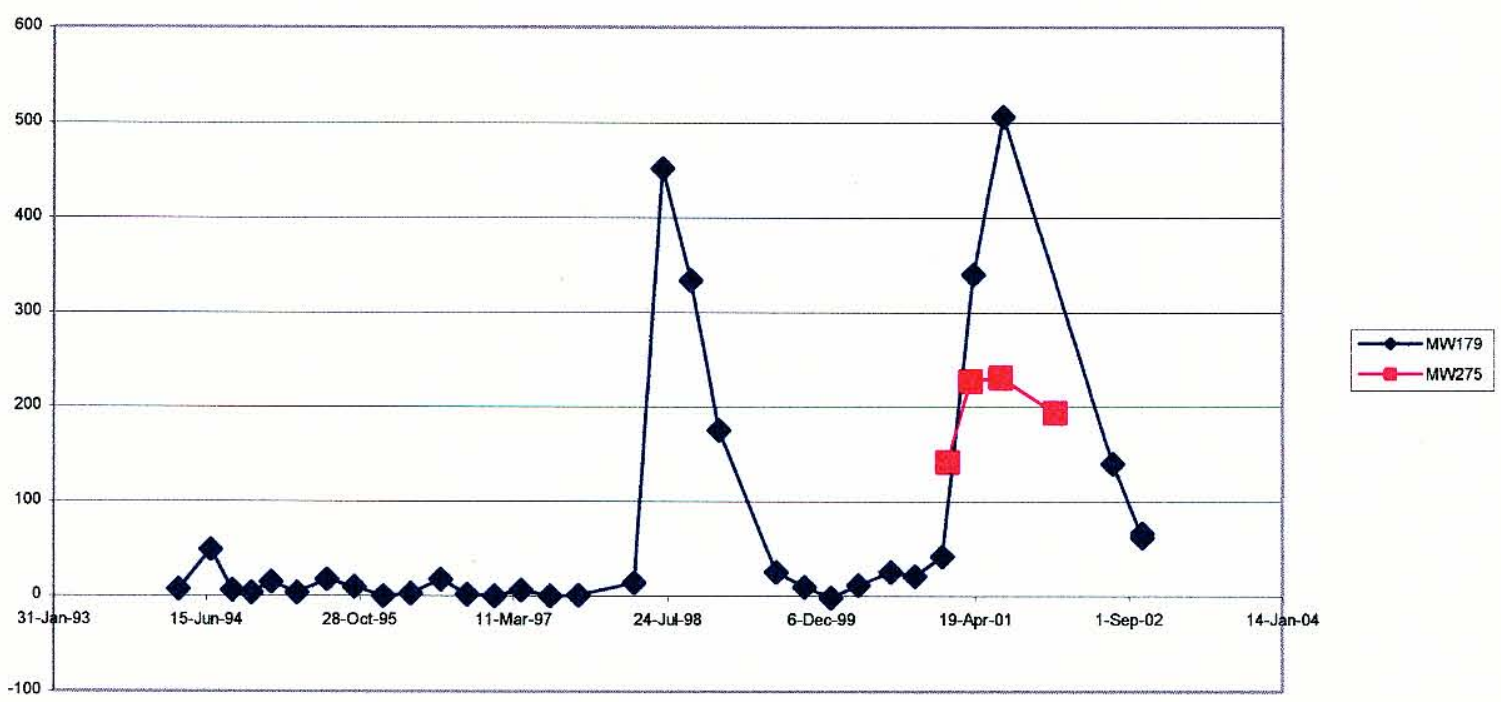

Figure 31 - TC-99 Activity Plot of MW 179 and MW 275 


\section{Leachate Analysis}

If the landfills are leaking, then it is appropriate to examine concentrations of contaminants other than just TCE and TC-99. If no contaminated material, such as TCE and TC-99, was placed in the landfills, then there would be no proof of leakage from the concentration and activity analyses. The leachate reports used for the analysis are provided in Appendix B. The following constituents were examined: Cadmium, Chlorides, COD, Iron, Lead, Sulfates, TOC, and Zinc.

Cadmium provides little to no evidence of landfill leakage. The maximum concentration measured in samples from the monitoring wells is $0.01 \mathrm{mg} / \mathrm{L}$. The average reading of Cadmium concentration is $0.005 \mathrm{mg} / \mathrm{L}$, or $5 \mu \mathrm{g} / \mathrm{L}$, in groundwater samples. The maximum leachate concentration for Cadmium is $3.4 \mu \mathrm{g} / \mathrm{L}$. The detection limit for the leachate sample is $5 \mu \mathrm{g} / \mathrm{L}$. Typical values of Cadmium in landfill leachate range from 0 to $0.6 \mathrm{mg} / \mathrm{L}$, or 0 to $60 \mu \mathrm{g} / \mathrm{L}$. (Vesilind et al., p.127). Therefore, Cadmium cannot provide any evidence of landfill leakage.

Chlorides averaged $39 \mathrm{mg} / \mathrm{L}$ in groundwater samples from the monitoring wells. The monitoring well samples showed a maximum chloride concentration value of $316 \mathrm{mg} / \mathrm{L}$. Typical values for chlorides in landfill leachate range from 6.2 to $67,000 \mathrm{mg} / \mathrm{L}$ (Vesilind et al., p. 127). Once again, the chlorides fall in the lower range of concentration, providing no evidence of landfill leakage.

The maximum concentration for iron from the monitoring well samples was 383 $\mathrm{mg} / \mathrm{L}$. The average concentration of iron was $3 \mathrm{mg} / \mathrm{L}$. The maximum iron concentration from the leachate reports is $950 \mathrm{mg} / \mathrm{L}$. Typical ranges for iron are 4 to $2200 \mathrm{mg} / \mathrm{L}$ in landfill leachate (Vesilind et al., p.127). The maximum concentration in groundwater is a fraction of 
that in the leachate, but the average iron concentration was low. The iron data show no signs of leakage from the landfills.

The maximum lead concentration recorded in the monitoring wells was $0.235 \mathrm{mg} / \mathrm{L}$, or $235 \mu \mathrm{g} / \mathrm{L}$. The average lead concentration for the monitoring wells was $0.06 \mathrm{mg} / \mathrm{L}$, or 60 $\mu \mathrm{g} / \mathrm{L}$. Typical values for leachate from landfills range from 0 to $2.55 \mathrm{mg} / \mathrm{L}$, or $2550 \mu \mathrm{g} / \mathrm{L}$. (Vesilind et al., p.127). The leachate from the S landfill had a maximum lead concentration of $89 \mu \mathrm{g} / \mathrm{L}$. The leachate concentration was lower than the monitoring well concentrations. Data on lead do not support the theory of a leaking landfill.

The maximum zinc concentration for the monitoring well samples was $2 \mathrm{mg} / \mathrm{L}$. The average concentration of zinc for the monitoring well samples was $0.12 \mathrm{mg} / \mathrm{L}$. Typical values of zinc from landfill leachate range from 0.005 to $846 \mathrm{mg} / \mathrm{L}$ (Vesilind et al., p.127). The leachate report for the $S$ landfill gives a zinc concentration of $0.9 \mathrm{mg} / \mathrm{L}$. Zinc data could be interpreted as giving weak evidence of leakage from the landfills.

TCE and TC-99 levels reported in the leachate from the S landfill show that little contaminated refuse was placed in the landfills. The maximum TC-99 activity was $3 \mathrm{pCi} / \mathrm{L}$. The maximum TCE concentrations present in the leachate do not exceed the detection limit. From these results, it can be concluded that there is little or no TCE or TC-99 present in the landfills.

The maximum value for Chemical Oxygen Demand, or COD, recorded in analysis of groundwater from around the S\&T landfills was $254 \mathrm{mg} / \mathrm{L}$. The average recorded COD for the monitoring well samples was $24.5 \mathrm{mg} / \mathrm{L}$. Typical values of COD in landfill leachate range from $11 \mathrm{mg} / \mathrm{L}$ to $84,000 \mathrm{mg} / \mathrm{L}$ (Vesilind et al., p. 127). The average COD falls into the lower range of values for leachate. COD does not provide evidence for landfill leakage. 


\section{CONCLUSIONS}

The cumulative analysis of the data shows that there is a very high probability that the landfills have not leaked TCE and TC-99. There is a plethora of evidence pointing to this conclusion.

1. The concentration plots show evidence of the landfills not being a source of TCE or TC-99. Plots of TCE concentrations and TC-99 activities versus time for each monitoring well group enforce the conclusion. Data from one monitoring well group does support the assumed groundwater flow direction and velocity, but do not support the possibility of a leak.

2. The Surfer plots also show no evidence of TCE or TC-99 leakage. The Surfer plots show strange patterns when the data are compared over time. The locations of higher concentrations or activities move around the site, and sometimes completely disappear.

3. The leachate analysis was directed at the contents of the landfill, to try to discover any possible leakage of key leachate chemicals. None of the concentrations show solid proof of leakage from the landfill.

The Surfer plots show recurring high concentrations of TCE located close to the old north-south drainage ditch, which was located north of the landfills. TCE was used as a degreasing agent, which could have been washed down the drains without any regard. The source of TCE contamination around the landfills could be the north-south drainage ditch. 
Figure 12 and Figure 31 suggest that plugs of TC-99 are travel from south of the landfills, across the landfills, and continue traveling in the groundwater flow direction. With the path of the slugs beginning south of the landfills, they cannot be sources of TC-99 contamination. With the assumption of funds available for the project, better techniques are available to address the issue of possible leakage from the S\&T landfills. A quick, accurate solution could be obtained by taking core samples in borings angled beneath the landfills. This method can provide groundwater for samples contaminant testing, to allow investigation of the effects of the landfill on groundwater quality and flow. 


\section{REFERENCES}

Agency for Toxic Substances and Disease Registry (ATSDR). 1997. Toxicological profile for trichloroethylene (TCE). Atlanta, GA: U.S. Department of Health and Human Services, Public Health Service.

Department of Energy (1997a). Progress Report, Characterization of Upper Continental Recharge System Heterogeneity and Uncertainity for the Paducah Gaseous Diffusion Plant, Paducah, Kentucky, JE/PAD/97-0137, United States Department of Energy, Paducah, KY, April 1, 1997.

Department of Energy (1997b). Ground-Water Conceptual Model for the Paducah Gaseous Diffusion Plant, DOE/OR/06-I628\&D0, United States Department of Energy, Paducah, KY, August 1997.

Department of Energy (2001). Old North-South Diversion Ditch Sampling Results, Paducah Gaseous Diffusion Plant, Paducah, Kentucky. DOE/OR/07-1929\&D1, United States Department of Energy, Paducah, KY, May 2001.

Ebbing, D.D. (1996). General Chemistry ${ }_{2} 5^{\text {th }}$ Edition, Houghton Mifflin Company, Boston, $1087 \mathrm{pp}$.

Goodyear Atomic Corporation (1978). Portsmouth Gaseous Diffusion Plant Environmental Monitoring Report for Calender Year 1977, GAT-955.

Hem, John D. (1978). Study of Interpretation of the Chemical and Characteristics of Natural Water, Second Edition. United States Government Printing Office, Washington.

Howard, P. (1991). Handbook of Environmental Fate and Exposure Data for Organic Chemicals, Volume II Solvents, Lewis Publishers.

Lenntech, www.lenntech.com/groundwater/iron.htm, April 11, 2006.

McConnell, C.L. (1992). "A Steady State Computer Model of the C-404 Landfill Area," in Resource Conservation and Recovery Act Part B Permit Modification for Inclusion of C-404 Low-Level Radioactive/Hazardous Waste Landfill, KY/E-129, Martin Marietta Energy Systems, Inc., Paducah Gaseous Diffusion Plant. 
National Primary Drinking Water Regulations. www.epa.gov/safewater/mcl.html. February $28,2006$.

Peacock, R.D., (1966) The Chemistry of Technetium and Rhenium, Elsevier Publishing Company, New York, NY.

Surfer version 8.04, Golden Software, Inc., Golden, Colorado.

Tchobanoglous, G., H. Theisen and S.A. Vigil (1993). Integrated Solid Waste Management. McGraw-Hill, New York, 978 pp.

Terran Corporation (1990). Groundwater Monitoring Phase II C-404 Aquifer Testing Program ESO 16749 Paducah Gaseous Diffusion Plant, Paducah, Kentucky., Report NO. TX-8925, Terran Corporation.

Till, J.E., Source Terms for Technetium-99 from Nuclear Fuel Cycle Facilities, Radiological Assessments Corporation, Nesses, South Carolina.

Union Carbide Corporation (1973). The Discard of Scrap Materials by Burial at the Paducah Plant, Paducah, KY, October.

Union Carbide Corporation (1977). Environmental monitoring report. Oak Ridge Facilities for Calendar Year 1976, Y/UB-6.

Vesilind, P. A., Worrell, W. A. and Reinhart, D. R. (2002). Solid Waste Engineering. Brooks/Cole, Pacific Grove, CA 428 pp.

Viessman, Jr., W. and M.J. Hammer (1998). Water Supply and Pollution Control. Addison Wesley Longman, Inc., Menlo Park, 827 pp. 
APPENDIX A - TYPICAL CHEMICAL ANALYSIS OF GROUNDWATER SAMPLES 


\begin{tabular}{|c|c|c|c|c|c|c|}
\hline$\underset{\mathrm{E}}{\text { STA NAM }}$ & D_COLLECTED & $\underset{\text { NAB_MEAS_CHEMICAL }}{\text { LAME }}$ & $\begin{array}{c}\text { LAB_MEAS } \\
\text { RESULTS }\end{array}$ & $\begin{array}{c}\text { LAB_MEA } \\
\text { S_UNITS }\end{array}$ & $\begin{array}{l}\text { DETECT } \\
\text { _LIMIT }\end{array}$ & RAD_ERR \\
\hline MW276 & 2-Apr-01 & Cadmium & 0.005 & $\mathrm{mg} / \mathrm{L}$ & 0.005 & \\
\hline MW276 & 2-Apr-01 & Iron & 1.16 & $\mathrm{mg} / \mathrm{L}$ & 0.2 & \\
\hline MW276 & 2-Apr-01 & Lead & 0.05 & $\mathrm{mg} / \mathrm{L}$ & 0.05 & \\
\hline MW276 & 2-Apr-01 & Zinc & 0.2 & $\mathrm{mg} / \mathrm{L}$ & 0.2 & \\
\hline MW276 & 2-Apr-01 & Technetium-99 & 68.9 & $\mathrm{pCi} / \mathrm{L}$ & 19.1 & 15 \\
\hline MW276 & 2-Apr-01 & Trichloroethene & 16 & $\mathrm{ug} / \mathrm{L}$ & 1 & \\
\hline MW276 & 2-Apr-01 & Chloride & 48.7 & $\mathrm{mg} / \mathrm{L}$ & 2 & \\
\hline MW276 & 2-Apr-01 & $\begin{array}{c}\text { Chemical Oxygen Demand } \\
\text { (COD) }\end{array}$ & 25 & $\mathrm{mg} / \mathrm{L}$ & 25 & \\
\hline MW268 & 2-Apr-01 & Zinc & 0.2 & $\mathrm{mg} / \mathrm{L}$ & 0.2 & \\
\hline MW268 & 2-Apr-01 & Technetium-99 & 42.3 & $\mathrm{pCi} / \mathrm{L}$ & 19.1 & 14.2 \\
\hline MW268 & 2-Apr-01 & Chloride & 21.1 & $\mathrm{mg} / \mathrm{L}$ & 2 & \\
\hline MW268 & 2-Apr-01 & $\begin{array}{c}\text { Chemical Oxygen Demand } \\
\text { (COD) }\end{array}$ & 25 & $\mathrm{mg} / \mathrm{L}$ & 25 & \\
\hline MW268 & 2-Apr-01 & Cadmium & 0.005 & $\mathrm{mg} / \mathrm{L}$ & 0.005 & \\
\hline MW268 & 2-Apr-01 & Trichloroethene & 2 & $\mathrm{ug} / \mathrm{L}$ & 1 & \\
\hline MW268 & 2-Apr-01 & Iron & 1.71 & $\mathrm{mg} / \mathrm{L}$ & 0.2 & \\
\hline MW268 & 2-Apr-01 & Lead & 0.05 & $\mathrm{mg} / \mathrm{L}$ & 0.05 & \\
\hline MW275 & 3-Apr-01 & Zinc & 0.2 & $\mathrm{mg} / \mathrm{L}$ & 0.2 & \\
\hline MW275 & 3-Apr-01 & Technetium-99 & 228 & $\mathrm{pCi} / \mathrm{L}$ & 19.1 & 19.3 \\
\hline MW275 & 3-Apr-01 & Trichloroethene & 1 & $\mathrm{ug} / \mathrm{L}$ & 1 & \\
\hline MW275 & 3-Apr-01 & Chloride & 37.8 & $\mathrm{mg} / \mathrm{L}$ & 2 & \\
\hline MW275 & 3-Apr-01 & \begin{tabular}{|c|}
$\begin{array}{c}\text { Chemical Oxygen Demand } \\
\text { (COD) }\end{array}$ \\
\end{tabular} & 25 & $\mathrm{mg} / \mathrm{L}$ & 25 & \\
\hline MW275 & 3-Apr-01 & Cadmium & 0.005 & $\mathrm{mg} / \mathrm{L}$ & 0.005 & \\
\hline MW275 & 3-Apr-01 & Iron & 1.5 & $\mathrm{mg} / \mathrm{L}$ & 0.2 & \\
\hline MW275 & 3-Apr-01 & Lead & 0.05 & $\mathrm{mg} / \mathrm{L}$ & 0.05 & \\
\hline MW272 & 2-Apr-01 & Zinc & 0.2 & $\mathrm{mg} / \mathrm{L}$ & 0.2 & \\
\hline MW272 & 2-Apr-01 & Technetium-99 & 37.6 & $\mathrm{pCi} / \mathrm{L}$ & 19.1 & 14 \\
\hline MW272 & 2-Apr-01 & Chloride & 53.4 & $\mathrm{mg} / \mathrm{L}$ & 2 & \\
\hline MW272 & 2-Apr-01 & $\begin{array}{c}\text { Chemical Oxygen Demand } \\
\text { (COD) }\end{array}$ & 25 & $\mathrm{mg} / \mathrm{L}$ & 25 & \\
\hline MW272 & 2-Apr-01 & Trichloroethene & 1 & $\mathrm{ug} / \mathrm{L}$ & 1 & \\
\hline MW272 & 2-Apr-01 & Cadmium & 0.005 & $\mathrm{mg} / \mathrm{L}$ & 0.005 & \\
\hline MW272 & 2-Apr-01 & Iron & 1.67 & $\mathrm{mg} / \mathrm{L}$ & 0.2 & \\
\hline MW272 & 2-Apr-01 & Lead & 0.05 & $\mathrm{mg} / \mathrm{L}$ & 0.05 & \\
\hline MW269 & 4-Apr-01 & Iron & 0.2 & $\mathrm{mg} / \mathrm{L}$ & 0.2 & \\
\hline MW269 & 4-Apr-01 & Lead & 0.05 & $\mathrm{mg} / \mathrm{L}$ & 0.05 & \\
\hline MW269 & 4-Apr-01 & Cadmium & 0.005 & $\mathrm{mg} / \mathrm{L}$ & 0.005 & \\
\hline MW269 & 4-Apr-01 & Zinc & 0.2 & $\mathrm{mg} / \mathrm{L}$ & 0.2 & \\
\hline MW269 & 4-Apr-01 & Technetium-99 & 82.1 & $\mathrm{pCi} / \mathrm{L}$ & 19.1 & 15.4 \\
\hline MW269 & 4-Apr-01 & Chloride & 30.6 & $\mathrm{mg} / \mathrm{L}$ & 2 & \\
\hline MW269 & 4-Apr-01 & $\begin{array}{c}\text { Chemical Oxygen Demand } \\
\text { (COD) }\end{array}$ & 25 & $\mathrm{mg} / \mathrm{L}$ & 25 & \\
\hline
\end{tabular}




\begin{tabular}{|c|c|c|c|c|c|c|}
\hline MW269 & 4-Apr-01 & Trichloroethene & 3 & $\mathrm{ug} / \mathrm{L}$ & 1 & \\
\hline MW274 & 3-Apr-01 & Chloride & 40.5 & $\mathrm{mg} / \mathrm{L}$ & 2 & \\
\hline MW274 & 3-Apr-01 & $\begin{array}{c}\text { Chemical Oxygen Demand } \\
\text { (COD) }\end{array}$ & 25 & $\mathrm{mg} / \mathrm{L}$ & 25 & \\
\hline MW274 & 3-Apr-01 & Cadmium & 0.005 & $\mathrm{mg} / \mathrm{L}$ & 0.005 & \\
\hline MW274 & 3-Apr-01 & Iron & 2.48 & $\mathrm{mg} / \mathrm{L}$ & 0.2 & \\
\hline MW274 & 3-Apr-01 & Lead & 0.05 & $\mathrm{mg} / \mathrm{L}$ & 0.05 & \\
\hline MW274 & 3-Apr-01 & Zinc & 0.2 & $\mathrm{mg} / \mathrm{L}$ & 0.2 & \\
\hline MW274 & 3-Apr-01 & Technetium-99 & 118 & $\mathrm{pCi} / \mathrm{L}$ & 19.1 & 16.5 \\
\hline MW274 & 3-Apr-01 & Trichloroethene & 1 & $\mathrm{ug} / \mathrm{L}$ & 1 & \\
\hline MW271 & 2-Apr-01 & Chloride & 25 & $\mathrm{mg} / \mathrm{L}$ & 2 & \\
\hline MW271 & 2-Apr-01 & $\begin{array}{c}\text { Chemical Oxygen Demand } \\
(\mathrm{COD})\end{array}$ & 25 & $\mathrm{mg} / \mathrm{L}$ & 25 & \\
\hline MW271 & $2-A p r-01$ & Cadmium & 0.005 & $\mathrm{mg} / \mathrm{L}$ & 0.005 & \\
\hline MW271 & 2-Apr-01 & Iron & 0.2 & $\mathrm{mg} / \mathrm{L}$ & 0.2 & \\
\hline MW271 & 2-Apr-01 & Lead & 0.05 & $\mathrm{mg} / \mathrm{L}$ & 0.05 & \\
\hline MW271 & 2-Apr-01 & Zinc & 0.2 & $\mathrm{mg} / \mathrm{L}$ & 0.2 & \\
\hline MW271 & 2-Apr-01 & Technetium-99 & 37.6 & $\mathrm{pCi} / \mathrm{L}$ & 19.1 & 14.1 \\
\hline MW271 & 2-Apr-01 & Trichloroethene & 1 & ug/L & 1 & \\
\hline MW273 & 2-Apr-01 & Zinc & 0.2 & $\mathrm{mg} / \mathrm{L}$ & 0.2 & \\
\hline MW273 & 2-Apr-01 & Technetium-99 & 113 & $\mathrm{pCi} / \mathrm{L}$ & 19.1 & 16.3 \\
\hline MW273 & 2-Apr-01 & Trichloroethene & 1 & $\mathrm{ug} / \mathrm{L}$ & 1 & \\
\hline MW273 & 2-Apr-01 & Chloride & 37.2 & $\mathrm{mg} / \mathrm{L}$ & 2 & \\
\hline MW273 & 2-Apr-01 & $\begin{array}{c}\text { Chemical Oxygen Demand } \\
\text { (COD) }\end{array}$ & 25 & $\mathrm{mg} / \mathrm{L}$ & 25 & \\
\hline MW273 & 2-Apr-01 & Cadmium & 0.005 & $\mathrm{mg} / \mathrm{L}$ & 0.005 & \\
\hline MW273 & 2-Apr-01 & Iron & 0.63 & $\mathrm{mg} / \mathrm{L}$ & 0.2 & \\
\hline MW273 & 2-Apr-01 & Lead & 0.05 & $\mathrm{mg} / \mathrm{L}$ & 0.05 & \\
\hline MW273 & 2-Apr-01 & Cadmium & 0.005 & $\mathrm{mg} / \mathrm{L}$ & 0.005 & \\
\hline MW273 & 2-Apr-01 & Iron & 0.254 & $\mathrm{mg} / \mathrm{L}$ & 0.2 & \\
\hline MW273 & 2-Apr-01 & Lead & 0.05 & $\mathrm{mg} / \mathrm{L}$ & 0.05 & \\
\hline MW273 & 2-Apr-01 & Zinc & 0.2 & $\mathrm{mg} / \mathrm{L}$ & 0.2 & \\
\hline MW273 & 2-Apr-01 & Technetium-99 & 98.6 & $\mathrm{pCi} / \mathrm{L}$ & 19.1 & 15.9 \\
\hline MW273 & 2-Apr-01 & Trichloroethene & 1 & $\mathrm{ug} / \mathrm{L}$ & 1 & \\
\hline MW273 & 2-Apr-01 & Chloride & 37.2 & $\mathrm{mg} / \mathrm{L}$ & 2 & \\
\hline MW273 & 2-Apr-01 & $\begin{array}{c}\text { Chemical Oxygen Demand } \\
(\mathrm{COD})\end{array}$ & 25 & $\mathrm{mg} / \mathrm{L}$ & 25 & \\
\hline
\end{tabular}


APPENDIX B - LANDFILL LEACHATE REPORTS 
STL ST. LOUIS

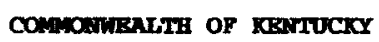

Client Sample ID: 080109

TOThL Metals

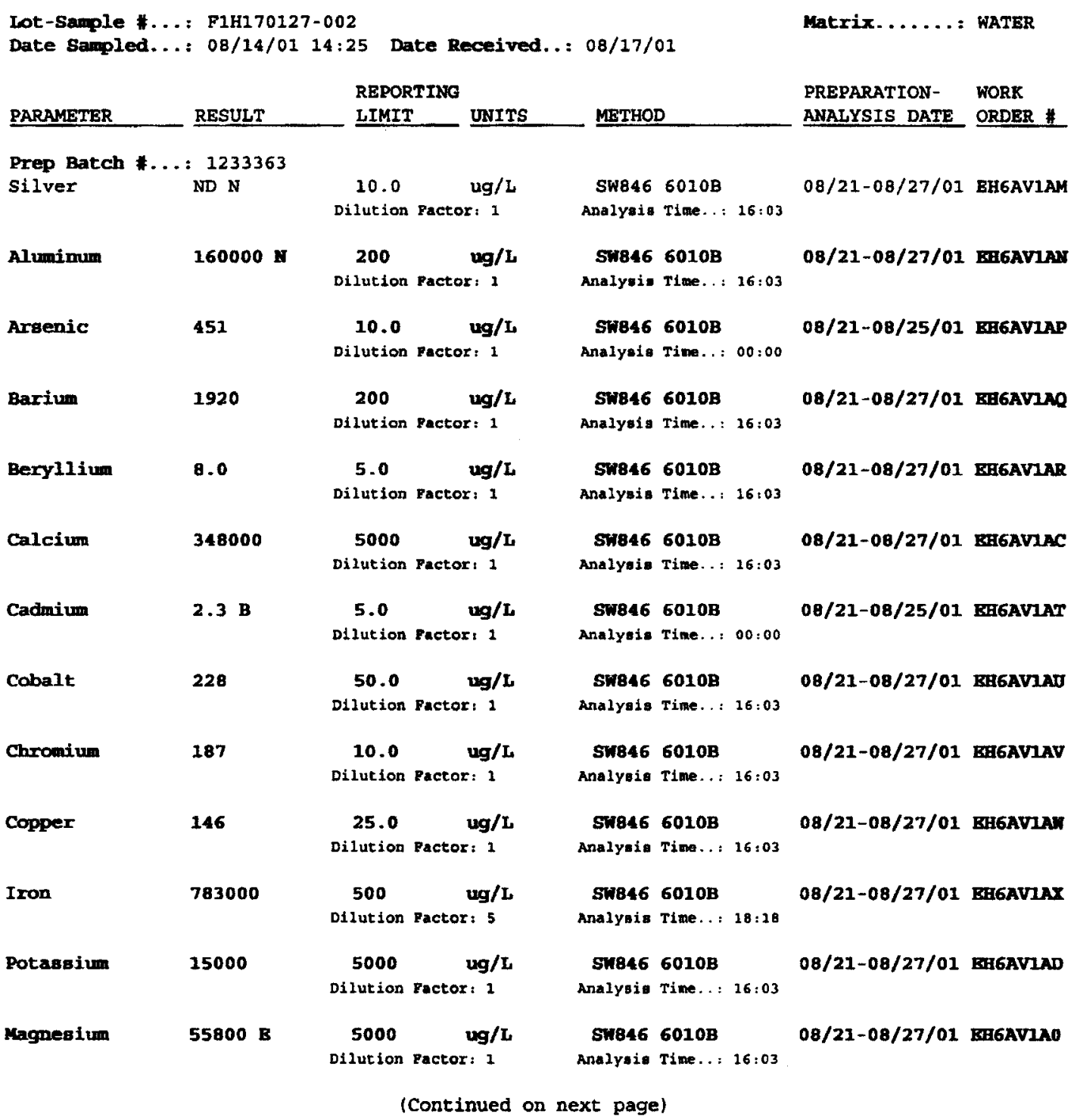


TOTaL Netals

Lot-Sample \#. . : F1H170127-002

Matrix........ WATER

\begin{tabular}{|c|c|c|c|c|c|c|c|c|}
\hline \multirow{2}{*}{$\frac{\text { PARAMETER }}{\text { Manganeie }}$} & \multirow{2}{*}{$\frac{\text { RESULT }}{3860}$} & \multirow{2}{*}{\multicolumn{2}{|c|}{$\begin{array}{l}\text { REPORTING } \\
\frac{\text { LIMIT }}{15.0} \frac{\text { UNITS }}{\mathrm{ug} / \mathrm{h}}\end{array}$}} & \multicolumn{3}{|c|}{ METHOD } & \multirow{2}{*}{$\begin{array}{l}\text { PRERARATION- } \\
\text { ANALYSIS DATE } \\
08 / 21-08 / 27 / 01\end{array}$} & \multirow{2}{*}{$\begin{array}{l}\text { WORK } \\
\text { ORDER \# } \\
\text { EHGAVIA9 }\end{array}$} \\
\hline & & & & 55846 & 60108 & & & \\
\hline & & Dilution & Pactor: 1 & Analysis & Tine..: & $16: 03$ & & \\
\hline \multirow[t]{2}{*}{ Nolybdenum } & 81.3 & 40.0 & ug/t. & Sw846 & $6010 B$ & & $08 / 21-08 / 27 / 01$ & BH6AVIA1 \\
\hline & & Dilution & Factor: 1 & Analysis & Time..: & $16: 03$ & & \\
\hline \multirow[t]{2}{*}{ Sodium } & 43300 & 5000 & $\mathbf{u g} / \mathrm{L}$ & SWB46 & 6010B & & $08 / 21-08 / 27 / 01$ & BA6AVIAB \\
\hline & & Dilution & pactor: 1 & Analyoi: & rim ..: & $16: 03$ & & \\
\hline \multirow[t]{2}{*}{ Hickel } & 232 & 40.0 & ug/L & SW846 & $6010 \mathrm{~B}$ & & $08 / 21-08 / 27 / 01$ & ERGAVIN2 \\
\hline & & Dilution & Mactor: 1 & Analyoiz & Time..: & $16: 03$ & & \\
\hline \multirow[t]{2}{*}{ Iead } & 89.3 & 3.0 & $\operatorname{ug} / \mathrm{L}$ & Sw846 & $6010 \mathrm{~B}$ & & $08 / 21-08 / 25 / 01$ & EHGAVIA3 \\
\hline & & Dilution & Pactor: 1 & Analysis: & Time..: & $00: 00$ & & \\
\hline \multirow[t]{2}{*}{ Antimony } & ND & 10.0 & ug/L & Sw846 & $6010 B$ & & $08 / 21-08 / 25 / 01$ & EH6AV1A4 \\
\hline & & Dilution & Pactor: 1 & Analyais & Time..: & $00: 00$ & & \\
\hline \multirow[t]{2}{*}{ Selenium } & 9.6 & 5.0 & $\operatorname{ug} / \mathrm{L}$ & Sw846 & $6010 \mathrm{~B}$ & & $08 / 21-08 / 25 / 01$ & Ea6AVIA5 \\
\hline & & Dilution & Factor: 1 & Analyois & rime..: & $00: 00$ & & \\
\hline \multirow[t]{2}{*}{ Thalliun } & $4.9 \mathrm{~B}$ & 10.0 & ug/L & $5 w 846$ & $6010 \mathrm{~B}$ & & $08 / 21-08 / 25 / 01$ & KA6AVIA6 \\
\hline & & Dilution & Factor: 1 & Analyaie & Time..: & $00: 00$ & & \\
\hline \multirow[t]{2}{*}{ Uranium } & ND & 500 & $\mathrm{ug} / \mathrm{L}$ & SW846 & $6010 B$ & & $08 / 21-08 / 27 / 01$ & EHGAV1AA \\
\hline & & Dilueton & Factor: 1 & Analysis & Time..: & $16: 03$ & & \\
\hline \multirow[t]{2}{*}{ Vanadiun } & 229 & 50.0 & ug/L & Sw846 & $6010 \mathrm{~B}$ & & $08 / 21-08 / 27 / 01$ & BH6AVIA7 \\
\hline & & Dllution & Factor: 1 & Asalyois & Time..: & $16: 03$ & & \\
\hline \multirow[t]{2}{*}{ zinc } & 902 & 20.0 & ug/L & Sw846 & $6010 \mathrm{~B}$ & & $08 / 21-08 / 27 / 01$ & BH6AVIAB \\
\hline & & Dilution & Factor: 1 & Aralyais & Time...: & $16: 03$ & & \\
\hline \multirow[t]{2}{*}{ Boron } & 210 & 200 & ug/L & Sw846 & $6010 \mathrm{~B}$ & & $08 / 21-08 / 27 / 01$ & EAH6AVLAP \\
\hline & & Dilut lon & Factor: 1 & Analysis & Time..: & $16: 03$ & & \\
\hline silicon & $94800 \mathrm{~N}$ & $\begin{array}{c}2500 \\
\text { Dilution }\end{array}$ & $\begin{array}{l}\text { ug/l } \\
\text { Factor: } 5\end{array}$ & $\begin{array}{r}\text { SW646 } \\
\text { Analygi }\end{array}$ & $\begin{array}{l}\text { 6010B } \\
\text { Time...: }\end{array}$ & $18: 18$ & $08 / 21-08 / 27 / 01$ & iAVLAG \\
\hline
\end{tabular}

(Continued on next page) 
STL ST. LOUIS

\section{COMEONARALTH OP KRITIJCKX}

Client Sanple ID: 080109

TOTAL Netals

Lot-Sample ...: F1H170127-002

Matrix........ : WATER

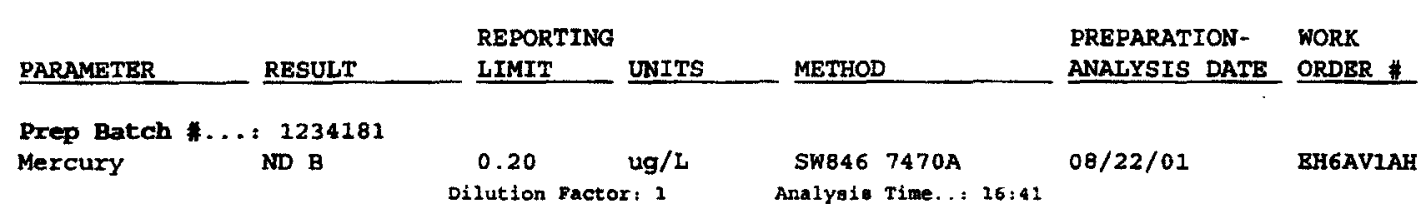

\section{$\operatorname{MOTB}(\mathrm{S}):$}

N Spiked andyce recovery is outside unted conerol linnits.

B Estimated rexolk. Ressuk is kess than RL.

E Matrix interference. 


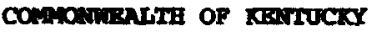

Client sample ID: 080109

GC/us volatilea

Iot-Sample *...: F1H170127-002 work Ordex ...: EH6AV1AL REPORTING

\section{PARAMETER}

Iodomethane

Ieobutanol

Methacrylonttrile

Methylene chloride

Methyl methacrylate

Pentachloroethane

Propionitrile

styrene

1, 1, 1,2-Tetrachloroethane

1,1,2,2-Tetrachloroethane

Tetrachloroethene

Toluene

1,1,1-Trichloraethane

1, 1,2-TIichlorgethane

Trichloroethene

1,2,3-Trichloropropane

Vinyl acetate

Vinyl chloride

XYlenes (total)

SURROGATE

4-Bromof luorobenzene

Toluene-d8

Dibromof luoromethane

1,2-Dichloroethane-ds

\section{RESULT}

ND

ND

ND

4.6 B

ND

ND

ND

ND

ND

ND

ND

ND

ND

ND

ND

ND

ND

ND

ND

PERCENT

RECOVERY

95

101

97

97
Matrix........ MATER

WNITS

$\mathrm{ug} / \mathrm{L}$

$u g / L$

$u g / L$

ug/L

$u g / L$

$u g / L$

$u g / L$

$u g / L$

ug/L

ug/L

ug/ L

$\mathrm{ug} / \mathrm{L}$

ug/L

$\mathrm{ug} / \mathrm{L}$

ug/L

$u g / L$

ug/L

ug/L

ug/L

MOTE(S):

J Extmaned resulk. Resuh is has than RL.

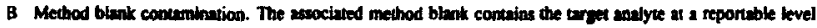


STL ST. LOUIS

\section{COMMONTEATH OF RENTUCKY}

Client Sample ID: 080109

Severn Trent Laboratories - Radiochemistry

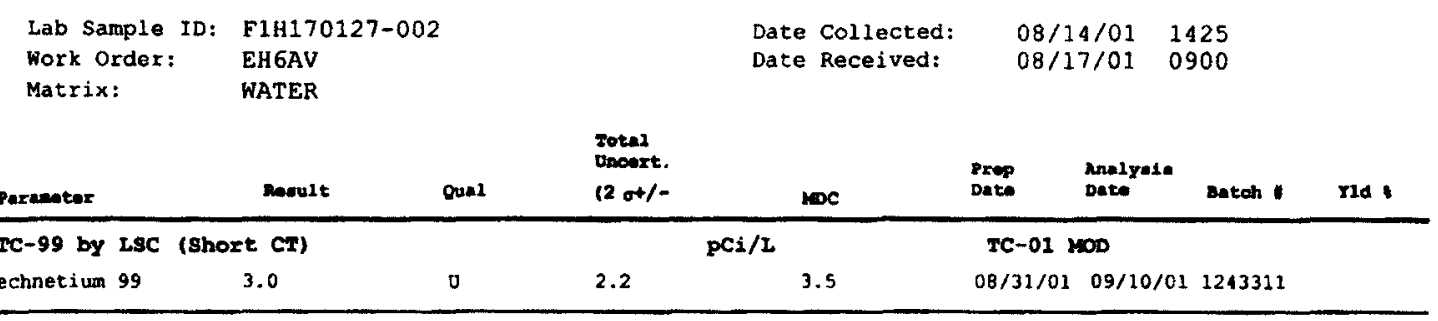

MOTE (s)

Date axe inecmplete without the oace narretive.

MoC is deternined by inetrueont pertormanoe only.

Bold reavite are grentar than the uDC

v Rowult is lese than the omple detection lifat. 


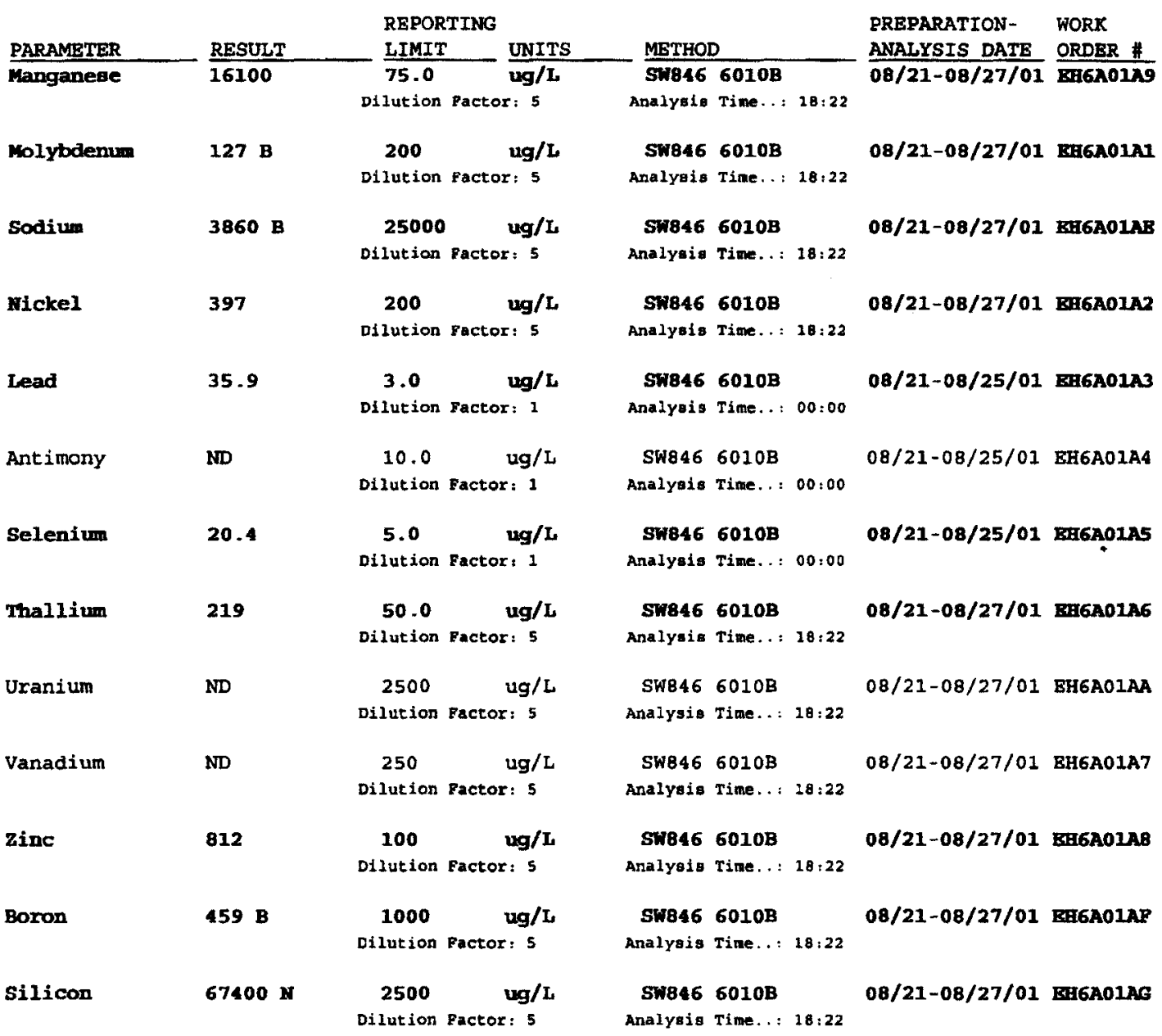


STL ST. LOUIS

CONOONTRALTH OF KEMTUCKY

Client Sample ID: 080110

TOTAL Metals

Lot-Sample \#...: F1H170127-003

REPORTING

PARAMETER

RESULT LIMIT

UNITS METHOD

PREPARATION- WORK

Prep Batch F...: 1234181

Mercury

ND

$0.20 \mathrm{ug} / \mathrm{L}$

Dilution Factor: 1

SW846 7470A

Analysis Time..: 16:43

ANALYSIS DATE ORDER \#

MOLB (S) :

N Spiked analyce recovery is outside stoed control limits.

B Estimaced resuk. Resuk is less than RL. 


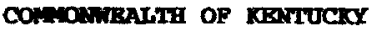

Client Sample ID: 080110

GC/us Volatiles

\begin{tabular}{|c|c|c|c|}
\hline Lot-Sanple ...: FIH17012 & Work Onder H...: & EH6A01AL & Natrix....... . : WATER \\
\hline PARAMETER & RESULT & $\begin{array}{l}\text { REPORTING } \\
\text { LIMIT } \\
\end{array}$ & UNITS \\
\hline Iodomethane & ND & 1.0 & $\mathrm{ug} / \mathrm{L}$ \\
\hline Isobutanol & ND & 50 & $\mathrm{ug} / \mathrm{L}$ \\
\hline Methacrylonitrile & ND & 1.0 & $\mathrm{ug} / \mathrm{L}$ \\
\hline Mathylene chlortide & $3.8 \mathrm{~B}$ & 1.0 & ug/L \\
\hline Methyl methacrylate & ND & 1.0 & ug/L \\
\hline Pentachloroethane & ND & 1.0 & $u g / L$ \\
\hline Propionitrile & ND & 4.0 & $\mathrm{ug} / \mathrm{L}$ \\
\hline styrene & ND & 1.0 & $u g / L$ \\
\hline 1,1,1,2-Tetrachloroethane & ND & 1.0 & $\mathrm{ug} / \mathrm{L}$ \\
\hline 1, 1,2,2-Tetrachloroethane & ND & 1.0 & $\mathrm{ug} / \mathrm{L}$ \\
\hline Tetrachloroethene & ND & 1.0 & $\mathrm{ug} / \mathrm{I}$ \\
\hline Toluene & ND & 1.0 & $\mathrm{ug} / \mathrm{I}$ \\
\hline 1,1,1-Trichloroethane & ND & 1.0 & $\mathrm{ug} / \mathrm{L}$ \\
\hline 1,1,2-Trichloroethane & ND & 1.0 & $\operatorname{ug} / \mathrm{L}$ \\
\hline Irichloroethene & $\mathrm{ND}$ & 1.0 & $\mathrm{ug} / \mathrm{L}$ \\
\hline 1,2,3-Trichloropropane & ND & 1.0 & $\operatorname{ug} / L$ \\
\hline Vinyl acetate & ND & 2.0 & $\mathrm{ug} / \mathrm{L}$ \\
\hline Vinyl chloride & ND & 2.0 & $\mathrm{ug} / \mathrm{L}$ \\
\hline xylenes (total) & ND & 1.0 & $u g / L$ \\
\hline & PERCENT & RECOVERY & \\
\hline SURROGATE & RECOVERY & LIMITS & \\
\hline 4-Bromofluorobenzene & $\overline{92}$ & $(72-116)$ & \\
\hline Toluene-d8 & 93 & $(79-124)$ & \\
\hline Dibromof luoromethane & 89 & $(71-128)$ & \\
\hline 1,2-Dichloroethane-d4 & 87 & $(65-126)$ & \\
\hline
\end{tabular}

MoIns (s) 
STL ST. LOUIS

\section{COMMONTEALTE OF RENTUCKY}

\section{Client Sample ID: 080110}

Severn Trent Laboratories - Radiochemistry

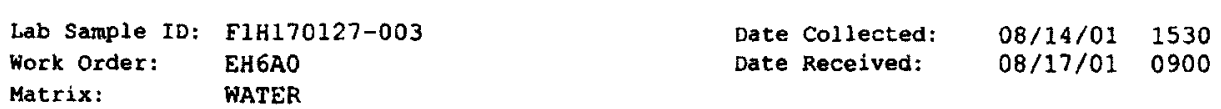

Date Received: $\quad 08 / 17 / 010900$

\begin{tabular}{|c|c|c|c|c|c|c|c|c|}
\hline Parmenoter & Reoult & Qual & $\begin{array}{l}\text { Total } \\
\text { Unoart. } \\
\text { (2 o+1- }\end{array}$ & MDC & $\begin{array}{l}\text { Prop } \\
\text { Dete }\end{array}$ & $\begin{array}{l}\text { Analyola } \\
\text { Date }\end{array}$ & Eatoh & nd \\
\hline TC- 99 by Lsc & (Short Cr) & & & & $T C-01$ & 1000 & & \\
\hline Technetium 99 & 2.1 & 0 & 2.3 & 3.8 & $08 / 31 / 01$ & $09 / 10 / 01$ & 1243311 & \\
\hline
\end{tabular}

Nort: (s)

Date are inowiplete without the cane narrative.

HDC is determined by lnatruant performance anly.

Bold reeulte are greater than the roc

$u$ Result is lese than the eample detection lindt. 


\section{VITA}

The author was born on January 14, 1981 in Hodgenville, Kentucky to David Cooper and Peggy Cooper. He graduated from LaRue County High School in May 1999. He received his Bachelor of Science in Civil and Environmental Engineering from the University of Louisville in May 2005 with Honors. In May 2006, Paul received the Master of Engineering Degree in Civil and Environmental Engineering from the University of Louisville. Paul was a member of Chi Epsilon, the University of Louisville American Society of Civil Engineers Student Chapter, and the University of Louisville Society of American Military Engineers Student Chapter. Paul enjoys fishing, hiking, and any outdoor activity. 